\title{
The effects of accounting standards on the financial reporting properties of private firms: evidence from the German Accounting Law Modernization Act
}

\author{
Julia Zicke ${ }^{1} \cdot$ Florian Kiy $^{2}$
}

Received: 14 January 2015/ Accepted: 20 July 2017 / Published online: 7 August 2017

(C) The Author(s) 2017. This article is an open access publication

\begin{abstract}
This study investigates whether the 2009 German Accounting Law Modernization Act has affected the reporting and accounting practices of German private firms. In reforming German accounting standards, numerous accounting options were deleted, several accounting rules were transferred from IFRS to German GAAP with some modifications, and disclosure requirements were extended. In our analysis, we examine the changes in financial reporting and their effects on disclosures. We use four financial reporting property measures: discretionary accruals, the correlation between operating cash flow and accruals, the persistence of earnings, and the predictability of earnings. The results reveal no change across all financial reporting properties. Examining disclosure compliance for capitalized development costs and other provisions reveals substantial variation in compliance.
\end{abstract}

Keywords German Accounting Law Modernization Act · German GAAP · Accounting standards · Financial reporting properties · Private firms

Julia Zicke

juliazicke@gmx.net

Florian Kiy

Kiy@wiwi.uni-frankfurt.de

1 Corporate Financial Reporting, SAP SE, Dietmar-Hopp-Allee 16, 69190 Walldorf, Germany

2 Accounting Department, Faculty of Economics and Business Administration, Goethe-

University Frankfurt am Main, Theodor-W.-Adorno-Platz 4, 60629 Frankfurt am Main,

Germany 


\section{Introduction}

Regulators and the accounting community are concerned with how accounting standards should be designed or changed to achieve financial reporting objectives. Higher quality accounting standards are supposed to positively affect firms' reporting quality and to be of greater value to users of financial statements. The German regulator implicitly acknowledged the growing influence of international accounting standards by enacting the German Accounting Law Modernization Act in 2009 in an attempt to make German GAAP align more closely with IFRS and to improve the information provided in German financial statements as a result. Specifically, modernizing national accounting law should result in a set of rules that is on par with international accounting standards, but more cost-effective and simpler to manage in practice (RegE BilMoG 2008).

This study presents the main changes in the accounting rules and disclosure requirements of German accounting law and examines their effects on financial accounting properties. As medium-sized non-listed companies were a target of the German Accounting Law Modernization Act, this investigation focuses on the consolidated financial statements of private firms. However, to exclude the possibility that macroeconomic effects are driving our results, we include as a control group private firms that release their financial statements under IFRS. With no capital market data in our treatment group, measures of reporting properties represent accounting-based measures, which are calculated using only financial statement data. We employ several accounting-based financial accounting property measures that have previously been implemented in prior research and test whether adopting the German Accounting Law Modernization Act had an impact on these measures. All German firms were required to adopt the new accounting standards in the fiscal year 2010. However, the regulator allowed early adoption in 2009 on a voluntary basis.

Our analysis is based on the magnitude of absolute discretionary accruals, the correlation between accruals and operating cash flow, the persistence of earnings, and the predictability of earnings as accounting-based financial reporting properties. The results of the main analysis, which uses a sample of German GAAP firms and German companies that report under IFRS, reveal an increase in discretionary accruals and no change in smoothing activities or in the persistence and the predictability of earnings. Certain significant differences in firm characteristics between the treated companies and the control companies raise concerns that our results are attributable to those differences. Hence, we employ a propensity score matching approach based on a probit regression to estimate the likelihood of releasing financial statements under German GAAP. The results of our propensity score matched sample confirm the results of our full sample for the last three financial reporting properties. However, propensity score matching applied to our discretionary accrual investigation reveals no significant differences, indicating that our results are most likely attributable to differences in firm characteristics. As with recent IFRS adoption studies (Daske et al. 2013; Christensen et al. 2015), we assume that changes in financial reporting properties may only be observable for 
those companies that will benefit from the German Accounting Law Modernization Act. We identify two sets of companies that might benefit from the application of the new rules. First, voluntary adopters should benefit from prior adoption; otherwise, they would not have voluntarily adopted these standards in advance. Second, companies that decide to capitalize their R\&D costs might benefit from the new accounting option, avoiding additional development expenses. Examining these subgroups of firms, we do not find a significant change in financial reporting properties compared to either mandatory adopters or companies that have R\&D activities that have not capitalized associated costs.

The German Accounting Law Modernization Act significantly increased disclosure requirements to guarantee that certain information was included in financial statements. Therefore, we investigate disclosure compliance for two important changes in German GAAP. First, we extend our prior investigation of companies' R\&D activities, since capitalizing companies must provide mandatory disclosures related to their R\&D activities in their notes. Second, we randomly select 300 companies and investigate their disclosures for other provisions, which are found in a balance sheet item whose measurement principles fundamentally changed after the adoption of the requirements. For both investigations, we find substantial variation in disclosure compliance.

This study contributes to the literature in several ways. The release of the first financial statements that adopted the German Accounting Law Modernization Act led to several studies examining their effects on accounting numbers and disclosures. One research stream focuses on the similarities between the new German GAAP and IFRS (Froschhammer and Haller 2012; Gross 2016; Pierk and Weil 2012; von Keitz et al. 2011). More specifically, the articles in this research stream analyze whether listed firms use the new set of accounting standards to align their German GAAP financial statements with their IFRS counterparts. von Keitz et al. (2011) examine the financial statements of 42 family firms on the DAXplus Family index. However, the results do not support the hypothesis that firms will engage in practices to bring German GAAP and IFRS financial statements closer together. Instead, they seem to remain in line with their tax accounting. Furthermore, Gross (2016) analyzes the effects on the comparability of private local GAAP and IFRS companies. Using aggregated output-based measures of de facto comparability, this author provides evidence for a significant increase in the comparability of accounting practices between German GAAP and IFRS companies following the adoption of the new accounting standards. Froschhammer and Haller (2012) use a sample of 362 unconsolidated accounts of public firms to confirm this fact. In particular, these authors analyze the adoption of ten accounting options, and their results demonstrate that only three options (regarding the valuation of pensions and two transition options) are exercised appropriately and aligned under IFRS. In addition, some studies concentrate exclusively on changes in specific accounting standards analyzing the capitalization of R\&D costs (Eierle and Wencki 2014) and accounting for pensions (Gassen et al. 2011; Pierk and Weil 2012). Eierle and Wencki (2014) examine the importance and determinants of the accounting option for capitalizing R\&D costs. Their sample consists of 586 large- and medium-sized private firms, and their results reveal that only a few companies choose to capitalize R\&D costs. Gassen et al. (2011) exploit a sample of 92 large firms that voluntarily adopted the new accounting standards 
in 2009 and analyze changes in accounting for pensions. Although pension liabilities increased by approximately $28.1 \%$, their results reveal poor disclosure quality in firms in which pension liabilities are not of great importance. Pierk and Weil (2012) investigate whether firms apply new local accounting rules to pensions to make their accounting numbers better align with IFRS. Exploiting a sample of 75 listed firms, the results generally support their hypothesis.

The first part of our study is closely related to Lopatta et al. (2013). Those authors investigate the effect of the German Accounting Law Modernization Act on discretionary accruals and identify a significant negative difference in the mean of discretionary accruals before and after the new rules were adopted. In addition to investigating discretionary accruals before and after the adoption of the German Accounting Law Modernization Act, we also use a variety of other financial reporting properties. Due to the distinctions between the subsamples of firms that might benefit from the German Accounting Law Modernization Act, we contribute to recent literature by providing separate evidence of the effects of the German Accounting Law Modernization Act on financial reporting properties for different private companies.

Additionally, we investigate whether private firms complied with extended disclosure requirements after the adoption of the German Accounting Law Modernization Act. Von Keitz and Gloth (2013) concentrate on the extent of disclosures in 54 listed firms and demonstrate that some firms provide more disclosures than required. However, other firms do not even appear to fulfill all of the mandatory disclosures. BDI et al. (2011) investigate the effects of the new accounting standards on a sample of 132 private firms and reach the same conclusion. We focus on the disclosure compliance for companies' R\&D activities and other provisions. Our results confirm prior findings with respect to the substantial variation in disclosure compliance.

Our contribution to this literature is to investigate the effect of the German Accounting Law Modernization Act on financial reporting properties and disclosure compliance. Furthermore, our investigation focuses exclusively on private companies, whereas the focus of most studies examining financial accounting properties or disclosure compliance is on public firms. Our results show that the financial reporting properties generally do not change after the adoption of the German Accounting Law Modernization Act. The remainder of this paper proceeds as follows. Section 2 provides an overview of the most important changes accompanying the German Accounting Law Modernization Act. The research design is presented in Sect. 3. Section 4 addresses sample selection and corresponding statistics. Section 5 presents the results of the primary and sensitivity analyses. Section 6 provides the conclusion.

\section{Changes in German GAAP enacted by the German Accounting Law Modernization Act}

Since the German Accounting Law Modernization Act resulted in numerous changes in German GAAP, the overview in Table 1 presents only the most significant of these changes regarding the recognition and measurement of assets and liabilities. The new accounting rules highlight the efforts of the German 
Table 1 A summary of the main changes in German GAAP under the German Accounting Law Modernization Act

\begin{tabular}{|c|c|c|}
\hline Position & $\begin{array}{l}\text { Regulation (old version of German } \\
\text { GAAP) }\end{array}$ & $\begin{array}{l}\text { Regulation (new version of } \\
\text { German GAAP) }\end{array}$ \\
\hline $\mathrm{R} \& \mathrm{D}$ assets & $\begin{array}{l}\text { Recognition prohibition for } \\
\text { internally generated intangible } \\
\text { assets }\end{array}$ & $\begin{array}{l}\S 248 \text { (2) Sentence 1: recognition } \\
\text { option } \\
\S 255 \text { (2a): capitalization of } \\
\text { development costs only } \\
\text { § } 248 \text { (2) Sentence 2: recognition } \\
\text { prohibition of internally } \\
\text { generated brands, mastheads, } \\
\text { publishing titles, customer lists, } \\
\text { and assets similar in substance }\end{array}$ \\
\hline $\begin{array}{l}\text { Business start-up and } \\
\text { expansion expenses }\end{array}$ & $\S 269$ : Recognition option & No longer applicable \\
\hline Acquired goodwill & $\begin{array}{l}\S 255 \text { (4): recognition option } \\
\S 255 \text { (4) Sentence 2: useful life of } \\
4 \text { years } \\
\S 255 \text { (4) Sentence } 3 \text { : scheduled } \\
\text { depreciation over the useful life } \\
\text { is allowed; however, in this case, } \\
\text { additional disclosure in notes is } \\
\text { required } \S 285 \text { No. } 13\end{array}$ & $\begin{array}{l}\S 246 \text { (1) Sentence } 4 \text { : recognition } \\
\text { obligation and scheduled } \\
\text { depreciation over the useful life } \\
\S 285 \text { No. 13: additional disclosure } \\
\text { in notes if the useful life exceeds } \\
5 \text { years }\end{array}$ \\
\hline Production costs & $\begin{array}{l}\S 255 \text { (2) Sentence } 3 \text { : valuation } \\
\text { option to include certain } \\
\text { overhead expenses }\end{array}$ & $\begin{array}{l}\text { No longer applicable, resulting in } \\
\text { an obligation to include these } \\
\text { expenses }\end{array}$ \\
\hline $\begin{array}{l}\text { Measurement methods for } \\
\text { inventory }\end{array}$ & $\begin{array}{l}\S 256 \text { : option to use LIFO, FIFO or } \\
\text { simplified methods }\end{array}$ & $\begin{array}{l}\S 256 \text { : option to use LIFO or FIFO, } \\
\text { prohibition for simplified } \\
\text { methods }\end{array}$ \\
\hline $\begin{array}{l}\text { Accruals for custom duties, } \\
\text { taxes and expenses for } \\
\text { VAT on advance } \\
\text { payments }\end{array}$ & $\begin{array}{l}\S 250 \text { (1) Sentence 2: recognition } \\
\text { option }\end{array}$ & No longer applicable \\
\hline Valuation units & $\begin{array}{l}\S 252 \text { (1) No. 3: separate valuation } \\
\text { is obligatory }\end{array}$ & $\begin{array}{l}\S 254 \text { : Formation of valuation units } \\
\text { is possible }\end{array}$ \\
\hline $\begin{array}{l}\text { Provision for deferred } \\
\text { maintenance at the end of } \\
\text { three months' time }\end{array}$ & $\begin{array}{l}\S 249 \text { (1) Sentence 3: recognition } \\
\text { option }\end{array}$ & No longer applicable \\
\hline Provision for expenses & $\S 249$ (2): recognition option & No longer applicable \\
\hline Liabilities & $\begin{array}{l}\S 253 \text { (1) Sentence } 2 \text { : valuation at } \\
\text { redemption amount }\end{array}$ & $\begin{array}{l}\S 253 \text { (1) Sentence 2: valuation at } \\
\text { settlement amount }\end{array}$ \\
\hline
\end{tabular}


Table 1 continued

\begin{tabular}{|c|c|c|}
\hline Position & $\begin{array}{l}\text { Regulation (old version of German } \\
\text { GAAP) }\end{array}$ & $\begin{array}{l}\text { Regulation (new version of } \\
\text { German GAAP) }\end{array}$ \\
\hline Provisions & $\begin{array}{l}\S 253 \text { (1) Sentence } 2 \text { : valuation at } \\
\text { the amount deemed necessary by } \\
\text { prudent commercial judgment as } \\
\text { of the reporting date and } \\
\text { prohibitions on discounting non- } \\
\text { interest-bearing provisions or on } \\
\text { considering future events }\end{array}$ & $\begin{array}{l}\S 253 \text { (1) Sentence } 2 \text { : valuation at } \\
\text { settlement amount and } \\
\text { consideration of future events is } \\
\text { obligatory } \\
\S 253 \text { (2) Sentence 1: long-term } \\
\text { provisions should be measured at } \\
\text { present value using a market } \\
\text { interest rate that is averaged out } \\
\text { over a period of seven years and } \\
\text { released by the German Central } \\
\text { Bank }\end{array}$ \\
\hline
\end{tabular}

Pension liabilities

Deferred Taxes

Write-downs of non-current assets

Write-downs of anticipated losses based on reasonable commercial assessment

Write-downs based on reasonable business judgment
$\S 253$ (1) Sentence 2: valuation at the amount deemed necessary by prudent commercial judgment as of the reporting date and a prohibition on considering future events

$\S 253$ (1) Sentence 2: valuation at present value. No rule for determining the interest rate.

$\S 274$ : Determination with the timing concept (focus on the income statement)

No consideration of losses carried forward

No consideration of hidden reserves resulting from consolidation

$\S 253$ (2) Sentence 3: option for write-downs in case of a temporary impairment

$\S 253$ (3) Sentence 3: option for write-downs

$\S 253$ (4): Option for write-downs
$\S 253$ (1) Sentence 2: valuation at settlement amount and consideration of future events is obligatory

$\S 253$ (2) Sentence 3: measurement at present value using a market interest rate released by the German Central Bank

$\S 274$ : Determination with the temporary concept (focus on the balance sheet)

Consideration of losses carried forward (§ 274 (1) Sentence 4)

Consideration of hidden reserves resulting from consolidation

$\S 253$ (3) Sentence 4: option restricted to financial assets

No longer applicable

No longer applicable

regulator to introduce a set of accounting standards that represent an alternative toand alignment with-IFRS without changing the main goals of German financial statements. Several accounting rules under the new act (e.g., capitalization of R\&D costs and valuation of provisions) are similar to their IFRS counterparts. However, the overview also highlights that certain differences remain. For example, the regulator introduced a recognition option for $\mathrm{R} \& \mathrm{D}$ costs, and there are no additional 
requirements for development costs (such as in IAS 38.57). In addition to the new recognition and measurement rules, the regulator also increased the amount of disclosure to improve the information provided in German financial statements. For example, if firms decide to capitalize $R \& D$ costs, they must disclose their total $R \& D$ costs and the related amount of capitalized $R \& D$ costs in notes $(\$ 285$ no. 22 German GAAP). Firms are also required to present R\&D assets separately on the balance sheet ( $\$ 266$ (2) German GAAP) and to present the development of these assets over the fiscal year in notes ( $\$ 284$ (3) German GAAP).

Overall, as several accounting options were abolished, the new accounting rules have the potential to improve the information provided in German financial statements. However, the introduction of new accounting options and of accounting rules that provide firms with even more discretion (e.g., considering future events in the fulfillment amount of provisions) may result in the transformation of certain financial reporting properties. Furthermore, if these new rules are obligatory rather than voluntary and if management incentives do not change, it may not be realistic to assume that financial reporting properties will change simply as the result of the application of new accounting standards (see also the results of Ball et al. 2003).

\section{Research design}

The previous literature has developed several proxies for financial reporting properties. In addition to market-based measures that rely on capital market data, there are also accounting-based measures that are calculated using financial statement data on an exclusive basis (see an overview of the main proxies in Francis et al. 2004). Since the German Accounting Law Modernization Act is obligatory for financial statements that apply German GAAP and for consolidated financial statements that are released by private companies, ${ }^{1}$ these firms do not provide capital market data to calculate market-based financial reporting property measures. Therefore, the proxies used in this investigation are accounting-based measures that rely solely on data provided by firms' financial statements.

Discretionary accruals are the first proxy used in this study. The literature argues that accruals have the potential to significantly influence net income because they do not result from cash flow streams, but touch the income statement instead (Dechow 1994). We use the cross-sectional version of the Jones model and the modified Jones model to estimate discretionary accruals as shown in models (1) and (2), respectively. As considering firm-specific coefficients would require multiple-year observations of one firm, we perform the regression on firms matched on year $t$ and industry $j$ as in DeFond and Jiambalvo (1994) and require a minimum of six observations per regression. Those year-industry combinations in which this requirement was not fulfilled were thus eliminated from the sample. To prevent the exclusion of firms in SIC 10-14 (mining industry) due to insufficient observations,

\footnotetext{
1 According to Regulation (EC) No. 1606/2002, listed German corporations are required to report their consolidated financial statements under IFRS since 2005.
} 
we added the observations of this industry to firms in SIC 15-17 (construction industry).

According to the Jones model, non-discretionary and discretionary accruals are estimated using the following model:

$$
\frac{\mathrm{TA}_{t}}{A_{t-1}}=\alpha_{0} \frac{1}{A_{t-1}}+\alpha_{1} \frac{\Delta \mathrm{REV}_{t}}{A_{t-1}}+\alpha_{2} \frac{\mathrm{PPE}_{t}}{A_{t-1}}+\varepsilon_{t} .
$$

Non-discretionary accruals are estimated using the change in revenues as well as property, plant, and equipment. The Jones model assumes that these variables control for changes in a firm's economic environment (Jones 1991). The error term signifies the component of accruals that cannot be explained by a firm's economic changes and is therefore considered the discretionary part of accruals.

Dechow et al. (1995) additionally subtract the change in receivables from the change in revenue, as they claim that management can also manage revenues using receivables. Therefore, non-discretionary and discretionary accruals are estimated according to their modified version of the Jones model using the following model:

$$
\frac{\mathrm{TA}_{t}}{A_{t-1}}=\alpha_{0} \frac{1}{A_{t-1}}+\alpha_{1} \frac{\Delta \mathrm{REV}_{t}-\Delta \mathrm{REC}_{t}}{A_{t-1}}+\alpha_{2} \frac{\mathrm{PPE}_{t}}{A_{t-1}}+\varepsilon_{t} .
$$

Total accruals (TA) are generally measured following Dechow et al. (1995) as the year-to-year change in non-cash current assets (CA as current assets and CASH as cash assets) minus changes in current liabilities, excluding short-term debt and taxes payable (CL as current liabilities, STD as short-term debt, and TP as income taxes payable) less depreciation and amortization expenses (DEP):

$$
\mathrm{TA}_{\mathrm{it}}=\left(\Delta \mathrm{CA}_{\mathrm{it}}-\Delta \mathrm{CASH}_{\mathrm{it}}\right)-\left(\Delta \mathrm{CL}_{\mathrm{it}}-\Delta \mathrm{STD}_{\mathrm{it}}-\Delta \mathrm{TP}_{\mathrm{it}}\right)-\mathrm{DEP}_{\mathrm{it}} \cdot
$$

Since the database used in this investigation does not differentiate between longterm and short-term provisions, we assume that all provisions are short-term and include them in total accruals. ${ }^{2}$ In addition, the database does not contain information regarding income taxes payable. Thus, the total accruals measure used in this investigation contains these obligations. To test whether the German Accounting Law Modernization Act affected the use of absolute discretionary accruals, we employ the following regression model:

$$
\begin{aligned}
|\mathrm{DA}|_{\mathrm{it}}= & \beta_{0}+\beta_{1} \mathrm{GGAAP}_{\mathrm{it}}+\beta_{2} \mathrm{GALMA}_{\mathrm{it}}+\beta_{3} \mathrm{GGAAP}_{\mathrm{it}} \times \mathrm{GALMA}_{\mathrm{it}}+\beta_{4} \mathrm{SIZE}_{\mathrm{it}} \\
& +\beta_{5} \mathrm{LEV}_{\mathrm{it}}+\beta_{6} \mathrm{ROA}_{\mathrm{it}}+\beta_{7} \mathrm{GROWTH}_{\mathrm{it}}+\beta_{8}|\mathrm{OCF}|_{\mathrm{it}}+\text { Industry Dummies }+\varepsilon_{\mathrm{it}} .
\end{aligned}
$$

Absolute discretionary accruals (IDAl) as the dependent variable are estimated as the absolute value of the error term of the Jones model (Eq. (1)) and the modified Jones model (Eq. (2)). To disentangle the potential effects due to new accounting standards from potential macroeconomic effects, we use private German firms releasing their financial statements under IFRS as a control group. Therefore, the first independent variable, GGAAP, accounts for the set of accounting standards.

\footnotetext{
${ }^{2}$ However, we additionally test whether our results are robust by eliminating provisions from total accruals and assuming that all provisions are non-current liabilities. We run this analysis only for the first and second financial reporting properties (absolute discretionary accruals and correlation between accruals and operating cash flow) since provisions are not important in testing the persistence of earnings and the predictability of earnings. The results are consistent with the main analysis.
} 
GALMA represents an additional binary variable, indicating whether the financial statement applies the German Accounting Law Modernization Act. The majority of firms adopted the new rules in 2010. However, as discussed above, the regulator allowed early adoption in 2009. To detect those fiscal years in which firms applied the new accounting standards, we checked the notes of the financial statements in 2009, as firms were required to disclose that they applied the new standards voluntarily [Section 66 (3) Sentence 6 Introductory Act to German GAAP]. Because the majority of private firms adopted the new accounting rules in 2010, we suggest the same behavior for IFRS firms. Thus, our GALMA coefficient equals one for all firm-year observations of our IFRS firms after 2009 and zero otherwise. For our German GAAP firm-year observations, GALMA equals one for all mandatory adopters starting in 2010 and for all voluntary adopters starting in 2009. We also include an interaction term, GGAAP $\times$ GALMA, to identify the additional effects of the new accounting standards in private firms releasing financial statements under German GAAP.

In addition, several variables are used to control for firm-specific incentives and firm-specific factors that might have an effect on absolute discretionary accruals. Without including additional control variables, the observed effects on absolute discretionary accruals might be falsely attributed to accounting standards rather than to incentives or innate determinants. In addition, in some performance situations, firms present a different pattern of accruals. Not controlling for these specific performance situations might lead to attributing the observed effects to changes in accounting standards. Therefore, we include firm size, leverage, profitability, growth, and the absolute value of operating cash flow as firm-specific controls and industry dummies to control for industry fixed effects. Following Petersen (2009), standard errors in all regression models in this study are clustered by firm.

We expect that leverage (LEV), growth (GROWTH), and the absolute value of operating cash flow $(|\mathrm{OCF}|)$ are positively associated with the value of absolute discretionary accruals. Firms with higher leverage tend to engage in incomeincreasing accruals to avoid breaking debt covenants (DeFond and Jiambalvo 1994), and growing firms are supposed to have larger positive accruals. The absolute value of operating cash flow is included because Dechow et al. (1995) show that as a result of the matching principle, negative (positive) non-discretionary accruals occur in periods with extreme positive (negative) cash flows. Further, we assume a negative sign for firm size (SIZE) and profitability (ROA), as firm size is a proxy for political attention and the political costs hypothesis contends that larger firms avoid earnings management activities to elude political attention (Watts and Zimmerman 1986). Less profitable firms have greater incentives to manage earnings upwards and therefore they will recognize lower income decreasing accruals and/or larger income-increasing accruals.

A second accounting-based financial reporting property measure is the correlation between accruals and operating cash flow as a proxy for earnings smoothing. This measure is based on Leuz et al. (2003), who investigated this correlation by firm. However, we adapt this measure to estimate a treatment effect in a differencein-difference research design. A negative correlation is a characteristic of accrual accounting (Dechow 1994). However, the magnitude of such a negative correlation 
indicates different degrees of earnings smoothing using accruals. Thus, examining whether the German Accounting Law Modernization Act had an impact on financial reporting properties, we analyze whether these new rules affected the magnitude of correlation between accruals and operating cash flow, where operating cash flow is calculated based on the relation between operating income and total accruals:

$$
\mathrm{OCF}_{\mathrm{it}}=\mathrm{OINC}_{\mathrm{it}}-\mathrm{TA}_{\mathrm{it}} \text {. }
$$

The regression model is as follows:

$$
\begin{aligned}
\mathrm{TA}_{\mathrm{it}}= & \beta_{0}+\beta_{1} \mathrm{GGAAP}_{\mathrm{it}}+\beta_{2} \mathrm{GALMA}_{\mathrm{it}}+\beta_{3} \mathrm{OCF}_{\mathrm{it}}+\beta_{4} \mathrm{OCF}_{\mathrm{it}} \times \mathrm{GGAAP}_{\mathrm{it}} \\
& +\beta_{5} \mathrm{OCF}_{\mathrm{it}} \times \mathrm{GALMA}_{\mathrm{it}}+\beta_{6} \mathrm{OCF}_{\mathrm{it}} \times \mathrm{GGAAP}_{\mathrm{it}} \times \mathrm{GALMA}_{\mathrm{it}}+\beta_{7} \mathrm{SIZE}_{\mathrm{it}} \\
& +\beta_{8} \mathrm{LEV}_{\mathrm{it}}+\beta_{9} \mathrm{ROA}_{\mathrm{it}}+\beta_{10} \mathrm{GROWTH}_{\mathrm{it}}+\text { Industry Dummies }+\varepsilon_{\mathrm{it}} .
\end{aligned}
$$

The interaction term OCF $\times$ GALMA indicates the difference in correlation before and after the German Accounting Law Modernization Act, and OCF $\times$ GGAAP represents the difference in correlation between German GAAP and IFRS firms. To test whether new accounting rules have had an additional effect on correlation between accruals and operating cash flow in private firms, we include another interaction term, $\mathrm{OCF} \times$ GGAAP $\times$ GALMA. As in our first regression function, we control for potential firm-specific incentives or firm-specific activities that might influence accruals. However, predictions regarding total accruals differ from predictions regarding discretionary accruals because total accruals are not completely driven by earnings management. For example, we assume that larger firms-where size is measured as the natural logarithm of total assets-have greater total accruals since positive accruals represent assets. Therefore, a firm with more positive accruals also owns larger assets and vice versa.

The persistence and the predictability of future earnings are two additional attributes of financial reporting properties derived from the time series construct of earnings (Schipper and Vincent 2003). Persistence is measured as the slope coefficient in a regression of current earnings on past earnings in which perfectly persistent earnings follow a random walk (Lev 1983). The measure of persistence quantifies the extent to which current performance is permanent and will recur in future periods (Lipe 1990). In addition, predictability implies that past financial reporting numbers can predict current performance. To measure the persistence and predictability of earnings, we use a linear relation between current and past earnings in which both variables are weighted by total assets in the corresponding fiscal year:

$$
E_{\mathrm{it}}=\beta_{0}+\beta_{1} E_{\mathrm{it}-1}+\text { Industry Dummies }+v_{\mathrm{it}} \text {. }
$$

The error term estimates the predictability of current earnings, and the slope coefficient $\beta_{1}$ measures the persistence of earnings. To answer the question as to whether the German Accounting Law Modernization Act has an effect on the predictability of earnings, we compare the means of the absolute value of error terms weighted by the dependent variable $\left(\left|v_{t} / E_{t}\right|\right)$ in the periods before and after the adoption of new accounting rules for German GAAP and IFRS firms. However, to test whether new rules had an impact on the persistence of earnings, we modify the regression function (7) as follows: 


$$
\begin{aligned}
E_{\mathrm{it}}= & \beta_{0}+\beta_{1} E_{\mathrm{it}-1}+\beta_{2} \mathrm{GGAAP}_{\mathrm{it}}+\beta_{3} \mathrm{GALMA}_{\mathrm{it}}+\beta_{4} E_{\mathrm{it}-1} \times \mathrm{GGAAP}_{\mathrm{it}} \\
& +\beta_{5} E_{\mathrm{it}-1} \times \mathrm{GALMA}_{\mathrm{it}}+\beta_{6} \mathrm{E}_{\mathrm{it}-1} \times \mathrm{GGAAP}_{\mathrm{it}} \times \mathrm{GALMA}_{\mathrm{it}} \\
& + \text { Industry Dummies }+\varepsilon_{\mathrm{it}} .
\end{aligned}
$$

In this modified regression model, the interaction term $E_{t-1} \times \mathrm{GGAAP}_{t}$ identifies the additional effect of accounting standards and $E_{t-1} \times \mathrm{GALMA}_{t}$ measures the additional effect of the German Accounting Law Modernization Act on the persistence of earnings. The term $E_{t-1} \times \mathrm{GGAAP}_{t} \times \mathrm{GALMA}_{t}$ signifies the difference in the persistence of earnings between German GAAP and IFRS firms before and after the adoption of the new rules.

One potential concern when comparing German companies that report under German GAAP to those reporting under IFRS is that the two groups might reveal differences in financial reporting properties due to their different economic characteristics (Barth et al. 2008). Although most German firms that report under IFRS are obligated to do so, our sample is restricted to voluntary adopters and therefore our research design suffers from a potential self-selection bias.

In attempting to control for those different characteristics between German private firms that report under IFRS and those companies that report under German GAAP, we employ a propensity score matching model. It is important to note that propensity score matching is not a suitable method to address concerns regarding correlated omitted variables. Propensity score matching is only appropriate if the relation between the control variables and the dependent variable (the outcome variable) is improperly specified [functional form misspecification (FFM)] (Rubin 1979). Hence, propensity score matching is a suitable instrument in our context only when all relevant influential factors concerning the reporting choice are observable and included in both regression types. Even with the inclusion of all relevant control variables, without propensity score matching, a potential bias still can arise from FFM. Based on the assumption that all relevant factors that determine the decision to report under German GAAP are considered, this procedure enables the artificial creation of a random sample in which the accounting system is randomly allocated to both the treatment and control group (Heckman and Navarro-Lozano 2004). When controlling for all relevant firm characteristics, any resulting differences between the two groups should be attributable to the treatment effect and not to preexisting client characteristics (Heckman et al. 1998; Dehejia and Wahba 2002), as matched companies are considered identical.

Based on the following probit regression, companies with similar probabilities of reporting under German GAAP are considered to be similar:

$$
\begin{aligned}
\operatorname{GGAAP}_{i, t}= & \beta_{0}+\beta_{1} \mathrm{SIZE}_{\mathrm{it}}+\beta_{2} \mathrm{LEV}_{\mathrm{it}}+\beta_{3} \mathrm{ROA}_{\mathrm{it}}+\beta_{4} \mathrm{GROWTH}+\beta_{5}|\mathrm{OCF}|_{\mathrm{it}} \\
& + \text { Industry Dummies }+ \text { Year Dummies }+\varepsilon_{\mathrm{it}} .
\end{aligned}
$$

The inclusion of industry and year fixed effects is based on the propensity score matching approach developed by Lawrence et al. (2011). Furthermore, the inclusion of industry dummies relies on Pierk and Weil (2016), who find evidence that priceregulated companies are more likely than non-regulated companies to adopt new 
accounting regulations early. Hence, industry classification can influence accounting choices, and we therefore include industry fixed in our probit regression.

Following Christensen et al. (2015), we include size, leverage and return on assets. These authors found a positive association between size and voluntary IFRS adoption and a negative association between IFRS adoption and leverage as well as return on assets. Further, growth and the absolute value of operating cash flow are included in our probit regression because stronger growing companies with higher operating cash flows tend to increase market shares in foreign companies, which, in turn, increases the potential need for external equity funding. Additionally, Gassen and Sellhorn (2006) find that international exposure, dispersion of ownership, and recent IPOs are important drivers of this phenomenon. International exposure might be an important driver, but our data source unfortunately does not contain specific information on foreign sales or turnover. Other determinants are negligible in the context of our private companies.

After estimating the propensity scores, we match (without replacement) companies that report under German GAAP with companies that report under IFRS and that have the closest predicted value from Eq. (9) within a maximum distance of $0.25 \%$. The results for a different caliper and an alternative matching approach are presented in Sect. 5.

\section{Sample selection and statistics}

The collected data cover the period from 2005 to 2014 and consolidated financial statements applying German GAAP and IFRS as a control group. Financial statement data were retrieved from the Amadeus-Bureau van Dijk database. This study focuses on consolidated accounts rather than on single accounts, because the primary objective of single accounts under German GAAP and German Tax Law is to determine distributable profit and tax payments. Providing information plays only a secondary role (Leuz and Wüstemann 2004). We exclude 436 listed firm-year observations of companies that apply German GAAP, because these firms are quite different from the private firms in our sample. Previously, we already deleted 6047 firms with missing prior year observations, of which 2158 observations are attributable to 2005 and which were only used to scale the variables by lagged total assets as well as to test the predictability and persistence of earnings. Therefore, 2005 data is used only indirectly.

As voluntary adoption was applicable to financial statements only after 12/31/ 2008 and mandatory adoption was required for financial statements beginning only after 12/31/2009, data with a 12/31 reporting date and data with a period of account different from the calendar year in the following year were summarized as data from the same year. For example, all observations with a reporting date of 12/31/2009 and observations in 2010 with a reporting date different from the calendar year (e.g., 03/31/2010) are interpreted as observations from 2009, because in this year the application of the German Accounting Law Modernization Act was permitted for the first time and mandatory application was required one period later. 
Consistent with prior studies that have analyzed accruals, we also exclude firms in the banking and insurance industry because their accrual process is different from that of industrial firms. In addition, we omit 31 observations with negative shareholder value. Our sample suffers an additional deduction of 1840 observations resulting from the data requirement mandating that there must be at least six companies in each industry by year to estimate discretionary accrual measures. Additionally, we omit 100 firm-year observations of SIC 10, due to non-existent variability in reporting practice. Finally, we also exclude all 3116 firm-year observations from listed companies reporting under IFRS, ${ }^{3}$ resulting in 22,894 firmyear observations. The sample contains fewer observations in 2006 due to numerous missing values as well as 2014 because not all financial statements under German GAAP had been published by the date of collection. ${ }^{4}$ Out of 2501 firms in 2009 , only 78 firms had voluntarily adopted the German Accounting Law Modernization Act. The sample uses 2151 IFRS firm-year observations as a control group. A detailed description of our sample selection process is presented in Table 2.

Table 3 presents the summary statistics for the subsamples of German GAAP and IFRS firms. The values of all the variables except for the binary variables are winsorized at the bottom and top $1 \%$. The summary statistics reveal considerable variation in all firm-specific characteristics. Thus, our results should not be biased to very small- or only medium-sized firms. Comparing German GAAP and IFRS firms, the results demonstrate that IFRS firms are on average larger and characterized by higher leverage.

The correlation matrix in Table 4 reveals that the largest correlation of variables used in the same regression function is between the absolute value of operating cash flow and total accruals. As discussed above, the negative correlation is the result of accrual accounting. All other correlations among the independent variables are lower. Thus, there is no concern that multicollinearity will affect the results.

\section{Empirical results}

\subsection{Results of the first-stage regression}

We match IFRS companies with German GAAP companies with the closest predicted value from Eq. (9) within a maximum distance of $0.25 \%$. Using this

\footnotetext{
3 The prior literature typically omits those firm-year observations before the estimation of discretionary accruals. However, because the majority of German IFRS companies represent listed companies and we require at least six firms in each industry per year to estimate discretionary accruals, a prior omission would significantly reduce our sample size. To prevent our sample from over-shrinking, we include those firm-year observations for estimation purposes and omit them afterward. However, we additionally perform our discretionary accruals estimation without those firm-year observations and do not obtain deviating results.

${ }^{4}$ However, we run an additional sensitivity analysis on a balanced sample to determine whether the results are affected by the fact that the sample changes systematically over time. The balanced sample consists of 347 firms in every year and a total of 3123 firm-year observations, and the results are consistent with the main results.
} 
Table 2 Sample selection process

\begin{tabular}{ll}
\hline & $\begin{array}{l}\text { \# Firm-year } \\
\text { observations }\end{array}$ \\
\hline $\begin{array}{l}\text { All consolidated firm-years in the Amadeus database with headquarters } \\
\text { in Germany from } 2005 \text { to } 2014\end{array}$ & 34,610 \\
Less firms with missing prior year observations & 6047 \\
Less publicly traded firms with German GAAP & 436 \\
Less firms with negative equity & 31 \\
Less observations from 2005 & 145 \\
Less duplications due to changes in reporting year & 1 \\
Additional deduction by data requirement (i.e., at least 6 firms in each industry & 1840 \\
by year) & 100 \\
Less firms of SIC 10, due to no variability in reporting practice & 3116 \\
Less listed IFRS observations & 22,894 \\
Sample size for the main tests with financial reporting properties & 2151 \\
Less firms reporting under IFRS & 20,743 \\
Sample size for the voluntary adoption test with financial reporting properties & 20,097 \\
Less firm-year observations of all companies without R\&D activities in the & \\
adoption period & \\
Sample size for the R\&D-specific tests with financial reporting properties & 646 \\
\hline
\end{tabular}

The sample selection process for our main tests, our subsample analysis of voluntary adopters and our subsample analysis of capitalizing companies with R\&D activities

caliper, we match approximately $17 \%$ of all firms in the sample. The results of the probit regression are presented in Table 5.

In line with our expectations, larger, less profitable, and stronger growing companies with a higher absolute cash flow from operations have a greater probability of adopting IFRS. Our results for the coefficients of SIZE and GROWTH are consistent with Dumontier and Raffournier (1998) and Barth et al. (2008), who found evidence that voluntary adoption of IFRS is positively associated with size and growth. As opposed to the findings previously described in the prior literature, our coefficient for LEV indicates a positive association between leverage and voluntary IFRS adoption. However, the deviating results may be attributable to the fact that previous studies mostly investigated voluntary IFRS adoption before IFRS reporting was mandatory for listed firms. Hence, their results are most likely driven by listed companies that have switched to IFRS and that should not be comparable to our results for private companies. Furthermore, although in line with Christensen et al. (2015), the ROA coefficient indicates a strong negative association between IFRS adoption and ROA.

To reduce the differences in firm characteristics between companies that report under IFRS and those reporting under German GAAP, we employ a matching 
Table 3 Descriptive statistics

\begin{tabular}{|c|c|c|c|c|c|c|}
\hline & $N$ & Mean & p50 & $\mathrm{SD}$ & $\mathrm{p} 25$ & $\mathrm{p} 75$ \\
\hline \multicolumn{7}{|l|}{ German GAAP } \\
\hline $\mathrm{TA}_{t} / A_{t-1}$ & 20,743 & -0.0535 & -0.0498 & 0.1175 & -0.1016 & -0.0011 \\
\hline$\left|\mathrm{DA}_{\text {Jones }}\right|$ & 20,743 & 0.0805 & 0.0525 & 0.0857 & 0.0237 & 0.1035 \\
\hline$\left|\mathrm{DA}_{\text {modJones }}\right|$ & 20,743 & 0.0816 & 0.0532 & 0.0871 & 0.0240 & 0.1048 \\
\hline GALMA & 20,743 & 0.6178 & & & & \\
\hline ASSETS & 20,743 & 238.1982 & 85.8778 & 532.0283 & 41.3214 & 200.7566 \\
\hline LEV & 20,743 & 0.6514 & 0.6546 & 0.2349 & 0.4912 & 0.7995 \\
\hline ROA & 20,743 & 0.0780 & 0.0649 & 0.0872 & 0.0265 & 0.1170 \\
\hline GROWTH & 20,743 & 5.9396 & 3.8962 & 19.9174 & -2.2128 & 11.4844 \\
\hline$|\mathrm{OCF}|$ & 20,743 & 0.1524 & 0.1238 & 0.1221 & 0.0681 & 0.2021 \\
\hline $\mathrm{OCF}$ & 20,743 & 0.1324 & 0.1163 & 0.1436 & 0.0549 & 0.1947 \\
\hline$E$ & 20,743 & 0.0389 & 0.0340 & 0.0697 & 0.0068 & 0.0717 \\
\hline \multicolumn{7}{|l|}{ IFRS } \\
\hline $\mathrm{TA}_{t} / A_{t-1}$ & 2151 & $-0.0475^{* *}$ & -0.0443 & 0.1287 & -0.0966 & 0.0047 \\
\hline$\left|\mathrm{DA}_{\text {Jones }}\right|$ & 2151 & $0.0897 * * *$ & 0.0531 & 0.1087 & 0.0225 & 0.1085 \\
\hline$\left|\mathrm{DA}_{\text {modJones }}\right|$ & 2151 & $0.0897 * * *$ & 0.0532 & 0.1080 & 0.0231 & 0.1104 \\
\hline GALMA & 2151 & 0.6165 & & & & \\
\hline ASSETS & 2151 & $1035.843^{* * *}$ & 309.6360 & 1562.3490 & 90.7670 & 1189.9220 \\
\hline LEV & 2151 & $0.6850 * * *$ & 0.6788 & 0.2426 & 0.5317 & 0.8187 \\
\hline $\mathrm{ROA}$ & 2151 & $0.0628 * * *$ & 0.0595 & 0.1043 & 0.0234 & 0.1051 \\
\hline GROWTH & 2151 & $9.0824 * * *$ & 4.2509 & 34.8340 & -3.7121 & 14.1835 \\
\hline$|\mathrm{OCF}|$ & 2151 & $0.1475^{*}$ & 0.1215 & 0.1155 & 0.0684 & 0.1896 \\
\hline $\mathrm{OCF}$ & 2151 & $0.1093 * * *$ & 0.1090 & 0.1522 & 0.0433 & 0.1804 \\
\hline$E$ & 2151 & $0.0262 * * *$ & 0.0309 & 0.0790 & 0.0012 & 0.0634 \\
\hline
\end{tabular}

$N$ represents the number of firm-year observations. TA $/ A_{t-1}$ are accruals in year $t$ calculated as in model (3), scaled by lagged total assets. $\left|\mathrm{DA}_{\text {Jones }}\right|$ and $\left|\mathrm{DA}_{\text {modJones }}\right|$ are the absolute values of the error terms of the Jones model (1) and of the modified Jones model (2). GALMA is a binary variable indicating whether the German Accounting Law Modernization Act is applied in year $t$. ASSETS are the total assets of the firm measured in million euro. LEV is computed as total assets minus book value of equity, scaled by lagged total assets. ROA is calculated as operating income in year $t$ divided by lagged total assets. GROWTH is the percent change in sales at year $t$ over a 1-year period. OCF is operating cash flow calculated as operating income less accruals in year $t$, scaled by lagged total assets. $|\mathrm{OCF}|$ is the absolute value of operating cash flow. $E$ is net income divided by total assets

$* / * * / * * *$ marks significance at $p<0.10 / p<0.05 / p<0.01$ levels, respectively

approach based on the results of propensity score estimates from Eq. (9) for every financial reporting property.

Table 6 presents the descriptive statistics of our full and propensity score matched sample. Insignificant differences in means relating to all control variables in the propensity score matched sample indicate that the model appears to be 


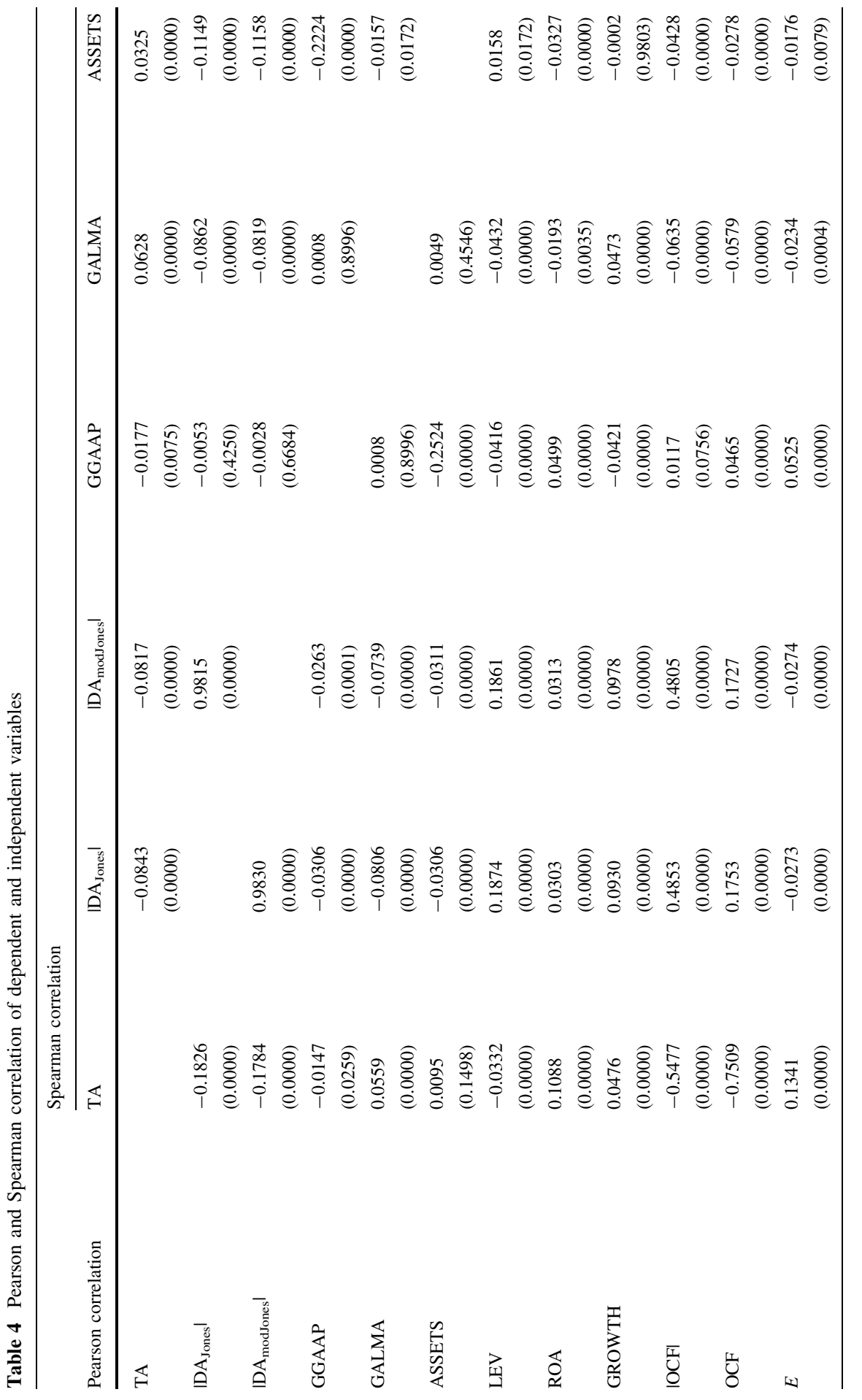




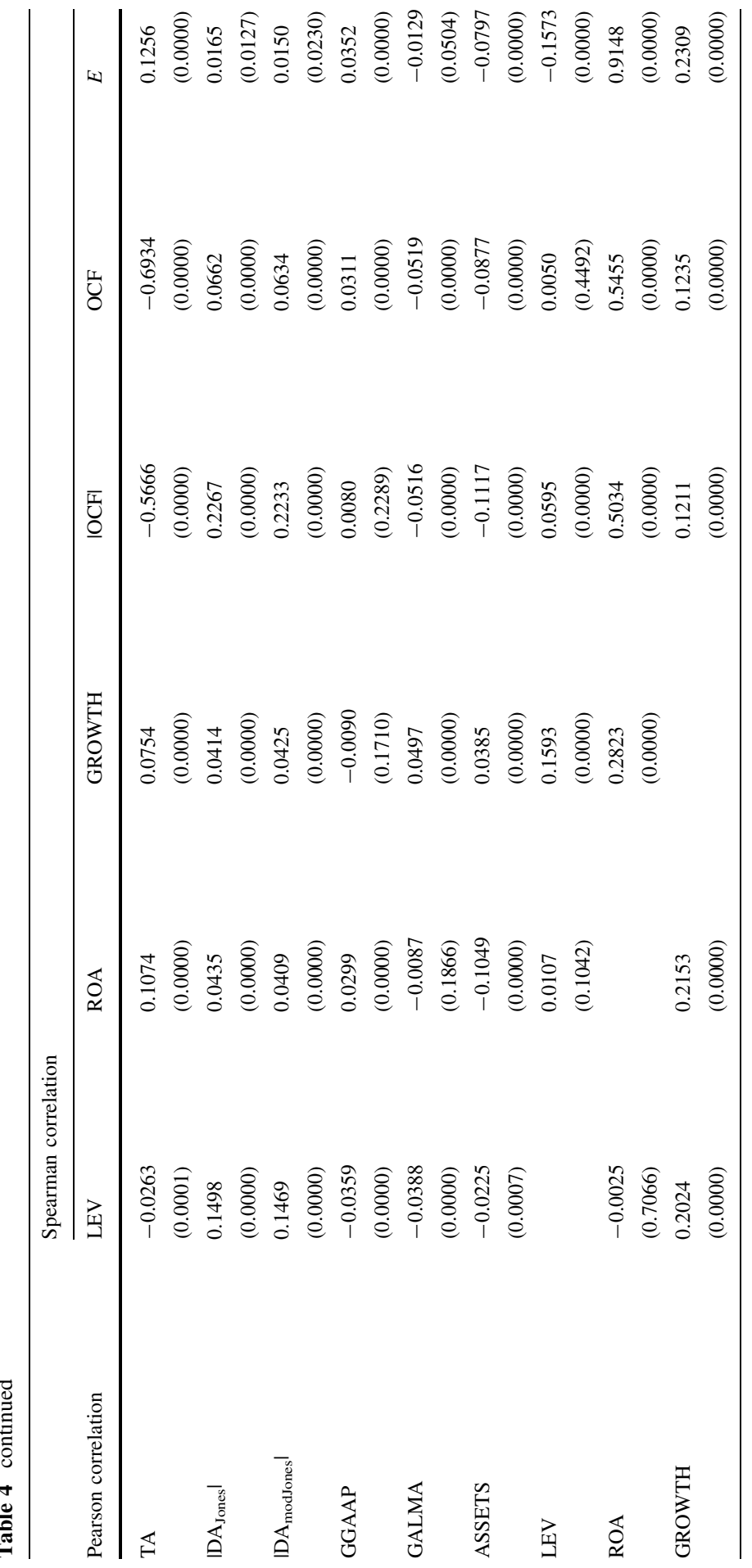




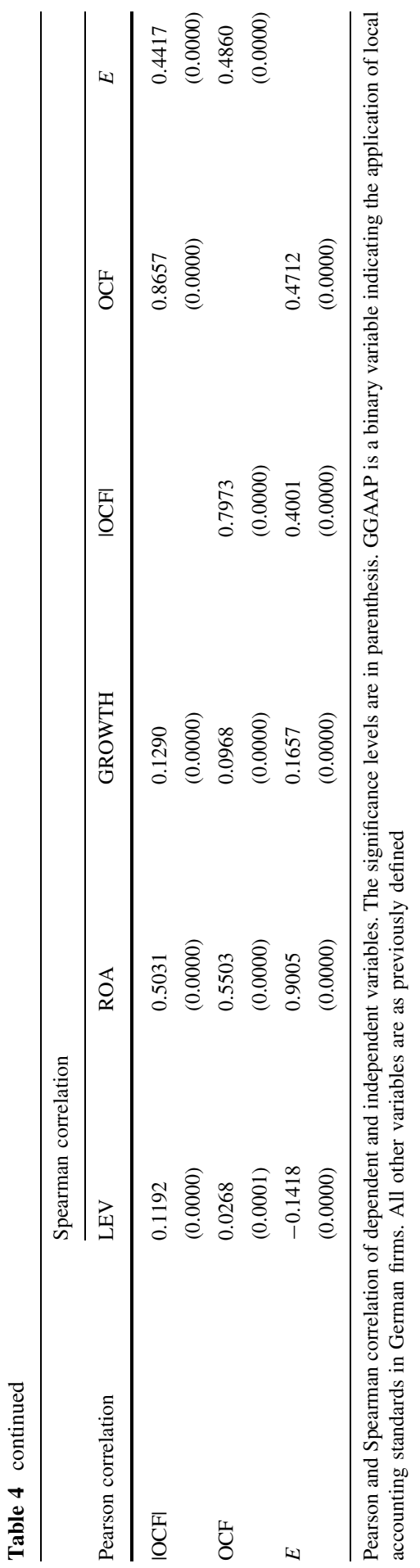


Table 5 First-stage regression-probit regression

(1) (2)

(3)

3)

(4)

\begin{tabular}{lllll}
\hline $\begin{array}{l}\text { Dependent variable: GGAAP } \\
\text { SIZE }\end{array}$ & $-0.3374 * * *$ & $-0.3555^{* * *}$ & $-0.3363^{* * *}$ & $-0.3546^{* * *}$ \\
& $(-37.69)$ & $(-38.56)$ & $(-37.45)$ & $(-38.34)$ \\
LEV & $-0.1542^{* * *}$ & $-0.1855^{* * *}$ & $-0.1569^{* * *}$ & $-0.1897 * * *$ \\
& $(-2.92)$ & $(-3.46)$ & $(-2.96)$ & $(-3.53)$ \\
ROA & $1.1422^{* * *}$ & $1.1756^{* * *}$ & $1.1239^{* * *}$ & $1.1530^{* * *}$ \\
& $(7.33)$ & $(7.44)$ & $(7.19)$ & $(7.26)$ \\
GROWTH & $-0.0031^{* * *}$ & $-0.0032^{* * *}$ & $-0.0032^{* * *}$ & $-0.0033^{* * *}$ \\
& $(-6.18)$ & $(-6.21)$ & $(-6.25)$ & $(-6.30)$ \\
IOCFI & $-0.5841^{* * *}$ & $-0.5722^{* * *}$ & $-0.5870^{* * *}$ & $-0.5765^{* * *}$ \\
& $(-5.10)$ & $(-4.95)$ & $(-5.11)$ & $(-4.97)$ \\
Intercept & $7.8218^{* * *}$ & 12.5322 & $7.8673^{* * *}$ & 12.4820 \\
& $(44.59)$ & $(0.10)$ & $(42.82)$ & $(0.12)$ \\
Industry fixed effects? & No & Yes & No & Yes \\
Year fixed effects? & No & No & Yes & Yes \\
$N$ & 22,894 & 22,894 & 22,894 & 22,894 \\
Pseudo $R^{2}$ & 0.118 & 0.133 & 0.121 & 0.135 \\
\hline
\end{tabular}

The estimation results of the probit regression to predict the probability to report based on German GAAP. SIZE is the natural logarithm of total assets in year $t$. All other variables are as previously defined $t$ statistics are in parentheses and $* / * * / * * *$ marks significance at $p<0.10 / p<0.05 / p<0.01$ levels, respectively

effective in creating a balanced sample of German GAAP and IFRS adopters. ${ }^{5}$ In addition, the standardized bias of all control variables before and after matching (Rosenbaum and Rubin 1985) is below 5\%, following the recommendation of Caliendo and Kopeinig (2008). ${ }^{6}$

\subsection{Results of the main analysis}

Table 7 demonstrates the results of the first analysis for the full and propensity score matched sample in which we test whether the German Accounting Law Modernization Act had an effect on the magnitude of absolute discretionary accruals. For our full sample (columns 1-4), the results show a negative effect of

\footnotetext{
${ }^{5}$ Notably, we use this propensity score matched sample for our first, third and fourth financial reporting properties. Since we include signed operating cash flow in our investigation of the correlation between operating cash flow and total accruals and Table 6 shows significant differences for signed operating cash flows, we adapt Eq. (9) and use signed operating cash flow instead of absolute operating cash flow.

${ }^{6}$ To mitigate concerns that our findings are a consequence of the smaller sample size in our propensity score matched sample, we adopt two additional matching approaches. First, we apply a matching approach with replacement and, second, we use our original matching approach with a higher caliper. Compared to our original matching approach, we observe no changes in the validity of our results (not tabulated).
} 
Table 6 Descriptive statistics-results for the full and propensity score matched sample

\begin{tabular}{|c|c|c|c|c|c|c|c|}
\hline & \multicolumn{4}{|c|}{ Full sample } & \multicolumn{3}{|c|}{$\begin{array}{l}\text { Propensity score matched sample: } \\
\text { matched using the full model }\end{array}$} \\
\hline & $\begin{array}{l}(1) \\
\text { All } \\
\text { obs. } \\
\text { mean }\end{array}$ & $\begin{array}{l}(2) \\
\text { German } \\
\text { GAAP } \\
\text { mean }\end{array}$ & $\begin{array}{l}(3) \\
\text { IFRS- } \\
\text { adopter } \\
\text { mean }\end{array}$ & $\begin{array}{l}(4) \\
\text { Differences in } \\
\text { means } \\
(t \text { statistics })\end{array}$ & $\begin{array}{l}(5) \\
\text { German } \\
\text { GAAP } \\
\text { mean }\end{array}$ & $\begin{array}{l}(6) \\
\text { IFRS- } \\
\text { adopter } \\
\text { mean }\end{array}$ & $\begin{array}{l}(7) \\
\text { Differences in } \\
\text { means } \\
(t \text { statistics })\end{array}$ \\
\hline $\mathrm{TA}_{t} / A_{t-1}$ & -0.053 & -0.053 & -0.047 & $\begin{array}{l}0.0060 \\
2.2273^{* *}\end{array}$ & -0.059 & -0.047 & $\begin{array}{l}0.0120 \\
2.9479 * * *\end{array}$ \\
\hline$\left|\mathrm{DA}_{\text {Jones }}\right|$ & 0.081 & 0.080 & 0.090 & $\begin{array}{l}0.0092 \\
4.6262 * * *\end{array}$ & 0.083 & 0.092 & $\begin{array}{l}0.0089 \\
2.745^{* * * *}\end{array}$ \\
\hline$\left|\mathrm{DA}_{\text {modJones }}\right|$ & 0.082 & 0.082 & 0.090 & $\begin{array}{l}0.0081 \\
3.9827 * * *\end{array}$ & 0.084 & 0.092 & $\begin{array}{l}0.0078 \\
2.4058 * *\end{array}$ \\
\hline GALMA & 0.618 & 0.618 & 0.616 & $\begin{array}{l}-0.0014 \\
-0.1262\end{array}$ & 0.620 & 0.612 & $\begin{array}{l}-0.0087 \\
-0.5601\end{array}$ \\
\hline SIZE & 18.517 & 18.398 & 19.666 & $\begin{array}{l}1.2677 \\
44.3679 * * *\end{array}$ & 19.417 & 19.354 & $\begin{array}{l}-0.0625 \\
-1.3835\end{array}$ \\
\hline LEV & 0.655 & 0.651 & 0.685 & $\begin{array}{l}0.0336 \\
6.2939 * * *\end{array}$ & 0.677 & 0.679 & $\begin{array}{l}0.0021 \\
0.2716\end{array}$ \\
\hline ROA & 0.077 & 0.078 & 0.063 & $\begin{array}{l}-0.0152 \\
-7.5573 * * *\end{array}$ & 0.065 & 0.063 & $\begin{array}{l}-0.0015 \\
-0.4871\end{array}$ \\
\hline GROWTH & 6.235 & 5.940 & 9.082 & $\begin{array}{l}3.1428 \\
6.3767 * * *\end{array}$ & 8.837 & 8.876 & $\begin{array}{l}0.0392 \\
0.0415\end{array}$ \\
\hline$|\mathrm{OCF}|$ & 0.152 & 0.152 & 0.148 & $\begin{array}{l}-0.0049 \\
-1.777 *\end{array}$ & 0.148 & 0.149 & $\begin{array}{l}0.0006 \\
0.1451\end{array}$ \\
\hline $\mathrm{OCF}$ & 0.130 & 0.132 & 0.109 & $\begin{array}{l}-0.0231 \\
-7.0455^{* * *}\end{array}$ & 0.125 & 0.109 & $\begin{array}{l}-0.0164 \\
-3.3845 * * *\end{array}$ \\
\hline$E$ & 0.038 & 0.039 & 0.026 & $\begin{array}{l}-0.0127 \\
-7.9483 * * *\end{array}$ & 0.031 & 0.026 & $\begin{array}{l}-0.0046 \\
-1.9629 * * *\end{array}$ \\
\hline No. obs. & 22,894 & 20,742 & 2151 & 22,894 & 1946 & 1946 & 3892 \\
\hline
\end{tabular}

This table presents the descriptive statistics for our full and propensity score matched sample. Propensity scores were calculated using Eq. (9). All variables are as previously defined

$* / * * / * * *$ marks significance at $p<0.10 / p<0.05 / p<0.01$ levels, using two-tailed $t$ tests of differences in means

GGAAP, meaning that German GAAP firms have lower absolute discretionary accruals than IFRS firms. The coefficient of GALMA is also negative and significant, indicating that absolute discretionary accruals are lower in the period following the German Accounting Law Modernization Act. However, the interaction term reveals that absolute discretionary accruals of German GAAP firms increase significantly following the adoption of the new accounting rules when compared to the control group of IFRS firms.

In addition, the coefficients of the control variables demonstrate the predicted signs. Consistent with the political cost hypothesis, larger firms present lower 


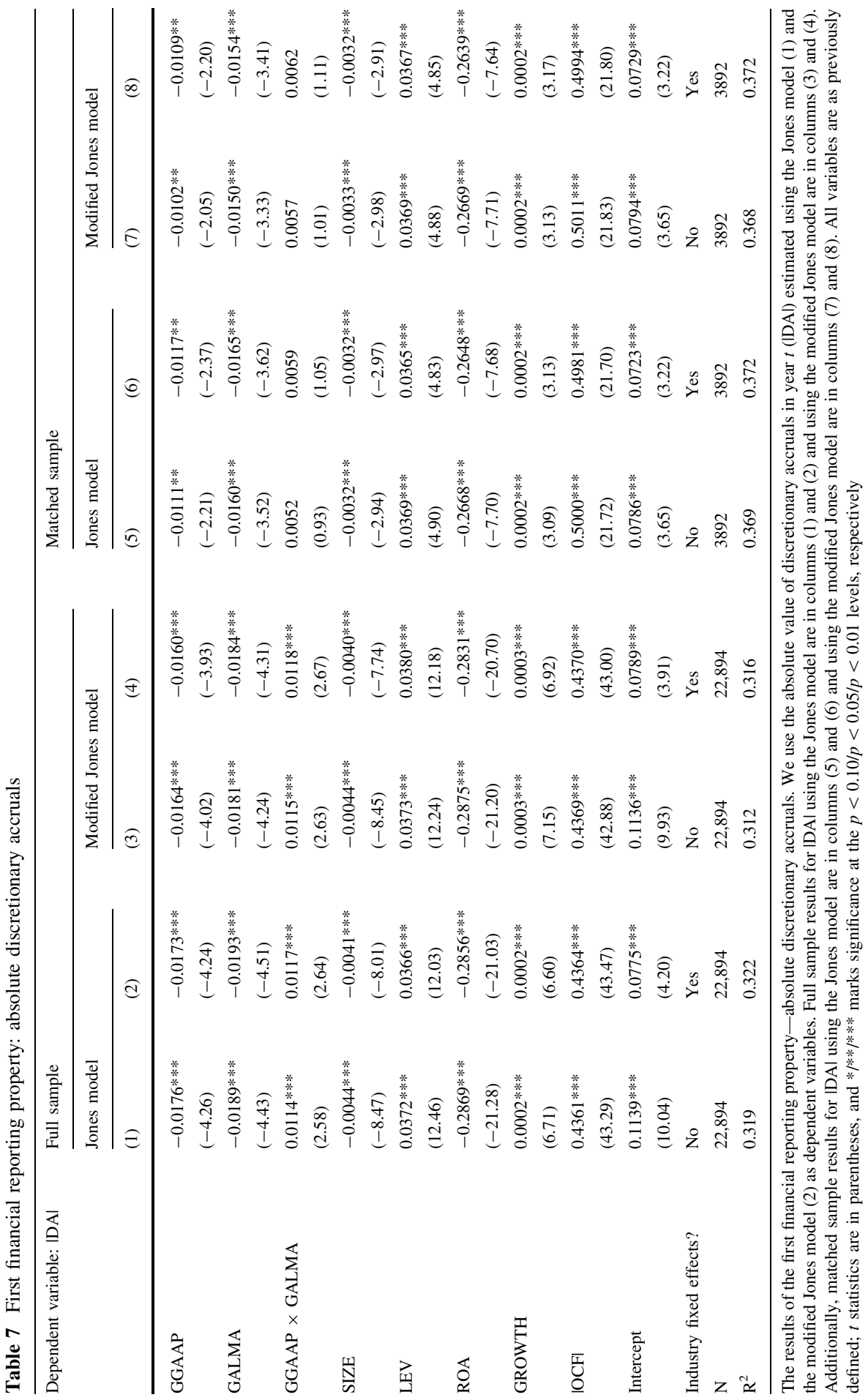


absolute discretionary accruals to avoid political attention. Higher leveraged firms tend to have greater absolute discretionary accruals based on the debt covenant hypothesis. In addition, firms with lower profitability and growing firms recognize larger absolute discretionary accruals. As hypothesized, the absolute value of operating cash flow is positively associated with absolute discretionary accruals. The last four columns of Table 7 present the results of the propensity score matched sample. Contrary to our full sample findings, our coefficient of interest, GGAAP $\times$ GALMA, is non-significant. Although it remains positive, the significance indicates that potential differences could be attributed to differences in firm characteristics. $^{7}$ Consistent with the results of the full sample, all control variable coefficients are significant and have the same directional effects and magnitude.

The analysis of the second financial reporting property in Table 8 reveals that the interaction term $\mathrm{OCF} \times$ GGAAP $\times$ GALMA is insignificant. Hence, our results indicate that the new accounting rules do not change the level of smoothing activities in financial statements under German GAAP. Our results from the propensity score matched sample provide confirmative evidence of this observation. Regarding control variables, operating cash flow is negatively correlated and profitability is positively related to total accruals in the full and in the propensity score matched sample, respectively. Additionally, we observe a significant positive association for firm size in the full sample, whereas we observe a non-significant positive association in the propensity score matched sample. Except for minor changes, the results remain consistent in our propensity score matched sample.

Testing the persistence of earnings in Table 9 and the predictability of earnings in Table 10, the results show no change in both financial reporting property measures under the German Accounting Law Modernization Act. The interaction term, $E_{t-1} \times \mathrm{GGAAP}_{t} \times \mathrm{GALMA}_{t}$, is not significant in either the full or the propensity score matched sample, demonstrating that the slope coefficient between past and current earnings is positive and unchanged after the new accounting rules are adopted by German GAAP firms. Nevertheless, it is positive, indicating that earnings are rather more persistent after adoption of the German Accounting Law Modernization Act. The $t$ test in Table 10 reveals no significant difference between the absolute values of the weighted error terms in regression (7). For our full sample, the error term decreased for IFRS and German GAAP firms after adopting the new accounting standards, while for German GAAP firms the decrease is smaller than for IFRS firms; however, this difference is not significant.

After restricting our sample to similar companies with a nearly identical probability to report under German GAAP, we nonetheless observe a decrease for the error term, which is again smaller for German GAAP firms than for IFRS firms. Nevertheless, the difference is also not significant. Therefore, the predictability of earnings has not changed after the new accounting rules are implemented.

\footnotetext{
7 Since previous models to estimate discretionary accruals (e.g., the Jones model and the modified Jones model) have been criticized in recent studies, we use three additional models to estimate nondiscretionary and discretionary accruals to check the robustness of our primary results. The first two alternative measures were developed by Dechow et al. (2003), and our third alternative measure was developed by Kothari et al. (2005). Our results remain consistent with our main analysis (not tabulated).
} 
Table 8 Second financial reporting property: correlation between accruals and operating cash flow

\begin{tabular}{|c|c|c|c|c|}
\hline \multirow[t]{2}{*}{ Dependent variable: TA } & \multicolumn{2}{|l|}{ Full sample } & \multicolumn{2}{|c|}{ Matched sample } \\
\hline & (1) & (2) & (3) & (4) \\
\hline GGAAP & $\begin{array}{l}-0.0020 \\
(-1.10)\end{array}$ & $\begin{array}{l}-0.0021 \\
(-1.17)\end{array}$ & $\begin{array}{l}-0.0012 \\
(-0.57)\end{array}$ & $\begin{array}{l}-0.0013 \\
(-0.61)\end{array}$ \\
\hline GALMA & $\begin{array}{l}0.0004 \\
(0.52)\end{array}$ & $\begin{array}{l}0.0004 \\
(0.47)\end{array}$ & $\begin{array}{l}0.0007 \\
(0.34)\end{array}$ & $\begin{array}{l}0.0006 \\
(0.31)\end{array}$ \\
\hline OCF & $\begin{array}{l}-0.9753 * * * \\
(-47.04)\end{array}$ & $\begin{array}{l}-0.9754 * * * \\
(-47.06)\end{array}$ & $\begin{array}{l}-0.9747 * * * \\
(-39.30)\end{array}$ & $\begin{array}{l}-0.9751^{* * *} \\
(-39.48)\end{array}$ \\
\hline $\mathrm{OCF} \times$ GGAAP & $\begin{array}{l}0.0228 \\
(1.10)\end{array}$ & $\begin{array}{l}0.0229 \\
(1.10)\end{array}$ & $\begin{array}{l}0.0309 \\
(1.06)\end{array}$ & $\begin{array}{l}0.0313 \\
(1.07)\end{array}$ \\
\hline OCF $\times$ GALMA & $\begin{array}{l}-0.0116 \\
(-0.49)\end{array}$ & $\begin{array}{l}-0.0117 \\
(-0.50)\end{array}$ & $\begin{array}{l}-0.0098 \\
(-0.36)\end{array}$ & $\begin{array}{l}-0.0095 \\
(-0.35)\end{array}$ \\
\hline OCF $\times$ GGAAP $\times$ GALMA & $\begin{array}{l}0.0157 \\
(0.68)\end{array}$ & $\begin{array}{l}0.0159 \\
(0.69)\end{array}$ & $\begin{array}{l}-0.0027 \\
(-0.09)\end{array}$ & $\begin{array}{l}-0.0022 \\
(-0.08)\end{array}$ \\
\hline SIZE & $\begin{array}{l}0.0007 * * * \\
(2.70)\end{array}$ & $\begin{array}{l}0.0007^{* * * *} \\
(2.71)\end{array}$ & $\begin{array}{l}0.0002 \\
(0.34)\end{array}$ & $\begin{array}{l}0.0002 \\
(0.38)\end{array}$ \\
\hline LEV & $\begin{array}{l}0.0002 \\
(0.13)\end{array}$ & $\begin{array}{l}0.0002 \\
(0.18)\end{array}$ & $\begin{array}{l}-0.0016 \\
(-0.37)\end{array}$ & $\begin{array}{l}-0.0010 \\
(-0.22)\end{array}$ \\
\hline ROA & $\begin{array}{l}0.9980^{* * * *} \\
(119.88)\end{array}$ & $\begin{array}{l}0.9985 * * * \\
(119.04)\end{array}$ & $\begin{array}{l}0.9884 * * * \\
(45.41)\end{array}$ & $\begin{array}{l}0.9891 \text { *** } \\
(45.71)\end{array}$ \\
\hline GROWTH & $\begin{array}{l}0.0000 \\
(-0.31)\end{array}$ & $\begin{array}{l}0.0000 \\
(-0.34)\end{array}$ & $\begin{array}{l}0.0000 \\
(0.43)\end{array}$ & $\begin{array}{l}0.0000 \\
(0.47)\end{array}$ \\
\hline Intercept & $\begin{array}{l}-0.0161^{* * *} \\
(-3.18)\end{array}$ & $\begin{array}{l}-0.0193 * * * \\
(-3.49)\end{array}$ & $\begin{array}{l}-0.0049 \\
(-0.55)\end{array}$ & $\begin{array}{l}-0.0132 \\
(-1.18)\end{array}$ \\
\hline Industry fixed effects? & No & Yes & No & Yes \\
\hline$N$ & 22,894 & 22,894 & 3908 & 3908 \\
\hline$R^{2}$ & 0.9549 & 0.9550 & 0.9459 & 0.9461 \\
\hline
\end{tabular}

This table presents the results of the second financial reporting property-the correlation between accruals and operating cash flow. All variables are as previously defined; $t$ statistics are in parentheses, and $* / * * / * * *$ marks significance at the $p<0.10 / p<0.05 / p<0.01$ levels, respectively

To sum up, the examination of financial reporting properties reveals no change in absolute discretionary accruals after controlling for differences in firm characteristics. Furthermore, all analyses imply no change in the selected accounting properties following adoption of the German Accounting Law Modernization Act. ${ }^{8}$

\footnotetext{
8 The variables in our regression models include values from the current year and the previous year (e.g., scaling by lagged total assets or including past earnings). Thus, in the adoption year, the measurement of the variables is based on information from the adoption year and on information from before the German Accounting Law Modernization Act was introduced. To rule out the possibility that this relation in preadoption values drives the results, we exclude the observations of the adoption year from our sample. Nevertheless, our results remain consistent with our main analysis (not tabulated).
} 
Table 9 Third financial reporting property-persistence of earnings

\begin{tabular}{|c|c|c|c|c|}
\hline \multirow[t]{2}{*}{ Dependent variable: $E_{t}$} & \multicolumn{2}{|l|}{ Full sample } & \multicolumn{2}{|c|}{ Matched sample } \\
\hline & (1) & (2) & (3) & (4) \\
\hline$E_{t-1}$ & $\begin{array}{l}0.5388 * * * * \\
(10.37)\end{array}$ & $\begin{array}{l}0.5381 * * * \\
(10.33)\end{array}$ & $\begin{array}{l}0.5358 * * * \\
(9.66)\end{array}$ & $\begin{array}{l}0.5357 * * * \\
(9.61)\end{array}$ \\
\hline $\mathrm{GGAAP}_{t}$ & $\begin{array}{l}0.0008 \\
(0.41)\end{array}$ & $\begin{array}{l}0.0011 \\
(0.54)\end{array}$ & $\begin{array}{l}0.0011 \\
(0.42)\end{array}$ & $\begin{array}{l}0.0013 \\
(0.51)\end{array}$ \\
\hline GALMA $_{t}$ & $\begin{array}{l}0.0016 \\
(1.51)\end{array}$ & $\begin{array}{l}0.0017 \\
(1.54)\end{array}$ & $\begin{array}{l}0.0003 \\
(0.13)\end{array}$ & $\begin{array}{l}0.0005 \\
(0.18)\end{array}$ \\
\hline$E_{t-1} \times \mathrm{GGAAP}_{t}$ & $\begin{array}{l}0.1336^{* *} \\
(2.52)\end{array}$ & $\begin{array}{l}0.1309^{* *} \\
(2.46)\end{array}$ & $\begin{array}{l}0.0405 \\
(0.59)\end{array}$ & $\begin{array}{l}0.0358 \\
(0.51)\end{array}$ \\
\hline$E_{t-1} \times \mathrm{GALMA}_{t}$ & $\begin{array}{l}0.0002 \\
(0.00)\end{array}$ & $\begin{array}{l}-0.0004 \\
(-0.01)\end{array}$ & $\begin{array}{l}0.0045 \\
(0.06)\end{array}$ & $\begin{array}{l}0.0017 \\
(0.02)\end{array}$ \\
\hline$E_{t-1} \times \mathrm{GGAAP}_{t} \times \mathrm{GALMA}_{t}$ & $\begin{array}{l}0.0207 \\
(0.33)\end{array}$ & $\begin{array}{l}0.0218 \\
(0.34)\end{array}$ & $\begin{array}{l}0.0949 \\
(1.22)\end{array}$ & $\begin{array}{l}0.0963 \\
(1.23)\end{array}$ \\
\hline Intercept & $\begin{array}{l}0.0094 * * * \\
(4.57)\end{array}$ & $\begin{array}{l}0.0081^{* *} \\
(2.09)\end{array}$ & $\begin{array}{l}0.0101 * * * \\
(3.79)\end{array}$ & $\begin{array}{l}0.0050 \\
(0.80)\end{array}$ \\
\hline Industry fixed effects? & No & Yes & No & Yes \\
\hline$N$ & 22,894 & 22,894 & 3892 & 3892 \\
\hline$R^{2}$ & 0.448 & 0.449 & 0.351 & 0.354 \\
\hline
\end{tabular}

The results of the third financial reporting property-persistence of earnings. $E_{t}$ and $E_{t-1}$ represent net income divided by total assets in the corresponding fiscal year. GGAAP $t$ and $\mathrm{GALMA}_{t}$ are binary variables indicating the application of local accounting standards in German firms and the application of the German Accounting Law Modernization Act in year $t$

All other variables are as previously defined; $t$ statistics are in parentheses, and $* / * * / * * *$ marks significance at the $p<0.10 / p<0.05 / p<0.01$ levels

\subsection{Subsample of voluntary adopters}

\subsubsection{Method for the subsample of voluntary adopters}

Our first analysis consists of observations for all firms that voluntarily adopted the new rules and for mandatory adopters. However, these subgroups may differ significantly in their incentives and therefore in their levels of financial reporting properties. It is possible that voluntary adopters welcomed the new rules and adopted them as soon as possible with the aim of improving the information provided in their consolidated statements. As the number of voluntary adopters in our sample is quite low (78 firms in 2009), it is possible that the effects of mandatory adopters outweigh the effects of voluntary adopters. To check whether the results for the financial reporting properties differ for voluntary adopters, we run an additional analysis. For the control group, we use mandatory GALMA adopters instead of IFRS companies. As described above, this research design also suffers a potential self-selection bias, as companies do not randomly decide to adopt 
Table 10 Fourth financial reporting property-predictability of earnings

\begin{tabular}{|c|c|c|c|c|c|c|c|c|}
\hline \multirow{3}{*}{ Statistic: mean $\left|v_{t} / E_{t}\right|$} & \multicolumn{4}{|c|}{ Full sample } & \multicolumn{4}{|c|}{ Matched sample } \\
\hline & \multicolumn{2}{|c|}{$\begin{array}{l}\text { GERMAN GAAP } \\
\text { firms }\end{array}$} & \multicolumn{2}{|c|}{ IFRS firms } & \multicolumn{2}{|c|}{$\begin{array}{l}\text { GERMAN GAAP } \\
\text { firms }\end{array}$} & \multicolumn{2}{|c|}{ IFRS firms } \\
\hline & (1) & (2) & (3) & (4) & (5) & (6) & (7) & (8) \\
\hline Before GALMA & 2.9173 & 2.9742 & 3.3861 & 3.3448 & 2.8617 & 2.7255 & 3.5795 & 3.5317 \\
\hline After GALMA & 2.4688 & 2.5136 & 1.9367 & 1.9430 & 2.0582 & 2.0491 & 1.9745 & 1.9800 \\
\hline$p$ value & 0.4148 & 0.4117 & 0.2814 & 0.2953 & 0.1653 & 0.2315 & 0.2744 & 0.2883 \\
\hline Industry fixed effects? & No & Yes & No & Yes & No & Yes & No & Yes \\
\hline $\mathrm{N}$ & 20,743 & 20,743 & 2151 & 2151 & 1946 & 1946 & 1946 & 1946 \\
\hline
\end{tabular}

The results of the fourth financial reporting property: the ability to predict earnings. This measure is calculated as the absolute value of the error term of regression (7) scaled by the dependent variable of regression (7). Then, the mean of this error term is computed for two subsamples (before and after the German Accounting Law Modernization Act) for German GAAP firms and for IFRS firms, separately, for the full and our propensity score matched samples. The significance of mean differences before and after the change in accounting standards is assessed by $t$ test

$* / * * / * * *$ marks significance at the $p<0.10 / p<0.05 / p<0.01$ levels

GALMA voluntarily. Therefore, the results might also be attributable to differences in pre-existing firm characteristics.

To control for those potential differences, we perform an additional probit regression based on Eq. (9) in Sect. 4. Notably, the decision to adopt the German Accounting Law Modernization Act on a voluntary basis differs from the previously investigated probit estimation of IFRS adoption with regard to the adoption year. In this case, companies can make the decision only for 2009. Hence, we follow the approach of Pierk and Weil (2016) and only include firm-year observations from this period in the probit regression. ${ }^{9}$ Then, we estimate propensity scores, which reflect the probability of adopting the German Accounting Law Modernization Act voluntarily. Consistent with our previous approach, we match (without replacement) companies with the closest predicted value within a maximum distance of $0.25 \%$. Notably, we apply this matching approach only for observations from 2009 and match companies with nearly identical probabilities to adopt the German Accounting Law Modernization Act voluntarily. Finally, we include all firm-year observations of those companies that are either in the treatment or control group.

\subsubsection{Results for the subsample of voluntary adopters}

Table 11 presents the results for our coefficients of interest. Both interaction terms for our absolute discretionary accrual measures are insignificant, with and without

\footnotetext{
9 Although we have no knowledge about the distribution of errors, we assumed a normal distribution of errors to employ a probit regression. However, Pierk and Weil (2016) employ a logit regression to analyze the determinants of voluntary adoption. Alternatively, we use a logit regression and do not observe any differences in our results.
} 
Table 11 Results of the financial reporting properties for the subsample of voluntary adopters

\begin{tabular}{|c|c|c|c|c|}
\hline & \multicolumn{2}{|c|}{ Full sample } & \multicolumn{2}{|c|}{ Matched sample } \\
\hline & (1) & (2) & (3) & (4) \\
\hline EARLY $\times$ GALMA $\left(\right.$ DA $\left._{\text {Jones }}\right)$ & $\begin{array}{l}-0.0060 \\
(-0.85)\end{array}$ & $\begin{array}{l}-0.0060 \\
(-0.85)\end{array}$ & $\begin{array}{l}0.0020 \\
(0.19)\end{array}$ & $\begin{array}{l}0.0019 \\
(0.18)\end{array}$ \\
\hline EARLY $\times$ GALMA $\left(\mathrm{DA}_{\text {modJones }}\right)$ & $\begin{array}{l}-0.0044 \\
(-0.63)\end{array}$ & $\begin{array}{l}-0.0043 \\
(-0.61)\end{array}$ & $\begin{array}{l}0.0044 \\
(0.42)\end{array}$ & $\begin{array}{l}0.0041 \\
(0.38)\end{array}$ \\
\hline OCF $\times$ EARLY $\times$ GALMA & $\begin{array}{l}0.0226 \\
(1.15)\end{array}$ & $\begin{array}{l}0.0222 \\
(1.13)\end{array}$ & $\begin{array}{l}0.0202 \\
(0.84)\end{array}$ & $\begin{array}{l}0.0208 \\
(0.86)\end{array}$ \\
\hline$E_{t-1} \times \operatorname{EARLY}_{t} \times \mathrm{GALMA}_{t}$ & $\begin{array}{l}-0.1202 * \\
(-1.70)\end{array}$ & $\begin{array}{l}-0.1184 * \\
(-1.67)\end{array}$ & $\begin{array}{l}-0.0907 \\
(-0.76)\end{array}$ & $\begin{array}{l}-0.0900 \\
(-0.75)\end{array}$ \\
\hline Difference in mean $\left|v_{t} / E_{t}\right|$ for voluntary adopters & 0.6286 & 0.6866 & 0.8623 & 0.9426 \\
\hline$p$ value & 0.2806 & 0.2485 & 0.2350 & 0.2055 \\
\hline Industry fixed effects? & No & Yes & No & Yes \\
\hline$N$ & 20,743 & 20,743 & 898 & 898 \\
\hline
\end{tabular}

The results of the coefficients of interest for our analysis of voluntary adopters. There are 567 firm-year observations of voluntary adopters, and German GAAP firms adopting the German Accounting Law Modernization Act on a mandatory basis are used as the control group. EARLY is a binary variable indicating whether the German Accounting Law Modernization Act was adopted voluntarily by the firm. All other variables are as previously defined. The significance of mean differences regarding the ability to predict earnings is assessed by $t$ test

$t$ statistics are in parentheses and $* / * * / * * *$ marks significance at the $p<0.10 / p<0.05 / p<0.01$ levels, respectively

the inclusion of industry controls. The interaction term OCF $\times$ EARLY $\times$ GALMA indicates that the magnitude of earnings smoothing is positive but also not significant. The coefficient measuring the effect on earnings persistence is negative and significant. However, after controlling for differences in firm characteristics, we observe a nonsignificant negative interaction term, $E_{t-1} \times$ EARLY $_{t} \times$ GALMA $_{t}$, with and without the inclusion of industry controls.

Regarding the ability to predict earnings, the $t$ test for the full and the propensity score matched sample does not reveal a significant change after adoption of the new accounting rules. Except for the persistence of the earnings interaction term, the significance of all other variables of interest does not change for our propensity score matched sample. Thus, the results for voluntary adopters indicate that the observed effects of the German Accounting Law Modernization Act do not differ between voluntary and mandatory adopters.

\subsection{Subsample of firms capitalizing $R \& D$ costs}

\subsubsection{Method for subsample of firms capitalizing $R \& D$ costs}

It is not clear whether one can see voluntary adopters as those firms that benefit from the new accounting rules because the difference in time between voluntary and 
mandatory adoption is only 1 year, and early adopters knew that they would (eventually) be required to adopt the new rules in 2010. The introduction of new accounting options makes it possible to identify those firms that benefit from the German Accounting Law Modernization Act. One of those accounting options is the option to capitalize development costs in $\S 248$ (2), Sentence 1, German GAAP. Thus, we checked the financial statements of voluntary and mandatory adopters in the adoption year to classify firms capitalizing R\&D costs. Based on our previous explanations, we expect companies to be dependent on key figures and ratios such as net income or equity ratio, since they are relevant when raising external funds and, additionally, capitalizing R\&D costs may avoid breaking covenants. Thus, those companies should benefit from the new set of accounting rules.

Deviating from the case of voluntary adoption of the German Accounting Law Modernization Act, companies regularly make the decision to capitalize these costs or not on a yearly basis for periods after the German Accounting Law Modernization Act. However, we only checked financial statements in the adoption year since there was no possibility to capitalize R\&D costs before, and it is highly probable that companies that plan to capitalize R\&D costs will capitalize such costs in the adoption year. Additionally, it is important to consider that only companies with $\mathrm{R} \& \mathrm{D}$ activities have the option to capitalize. Therefore, we restrict our subsample to companies with R\&D activities in the adoption year, and we employ our probit regression approach for this sample of voluntary and mandatory adopters in the adoption year, based on Eq. (9). Then, we estimate propensity scores, which reflect the probability of capitalizing $\mathrm{R} \& \mathrm{D}$ costs. Consistent with our previous approach, we include all firm-year observations of those companies that are either in the treatment or control group.

\subsubsection{Results for the subsample of firms capitalizing $R \& D$ costs}

The results of the probit regression (not tabulated) used for matching purposes indicate that companies that capitalize $R \& D$ costs are on average smaller, although this relationship is not statistically significant, but in line with the results of Eierle and Wencki (2014). Companies with greater leverage are more likely to capitalize R\&D costs, which is also consistent with prior literature (Eierle and Wencki 2014) since those companies either are more afraid of reporting negative earnings or have a smaller equity ratio. Return on assets is negatively associated with capitalization of R\&D costs. Because our full sample consists of only 646 firm-year observations, of which 339 are attributable to capitalizers, our propensity score matching approach decreases the sample to 461 observations.

Table 12 presents the results of the coefficients of interest for the subsample of companies with R\&D activities. The findings for absolute discretionary accruals are consistent with the results for voluntary adopters, indicating that the magnitude of the effect of the adoption of the German Accounting Law Modernization Act does not differ between capitalizing and non-capitalizing firms. Even the coefficient of the interaction term $\mathrm{OCF} \times \mathrm{CAP} \times$ GALMA is insignificant, indicating no change in income smoothing following adoption of the German Accounting Law Modernization Act. The findings for the persistence of earnings and for the 
Table 12 Results of financial reporting properties for the subsample of companies with R\&D activities

\begin{tabular}{|c|c|c|c|c|}
\hline & \multicolumn{2}{|c|}{ Full sample } & \multicolumn{2}{|c|}{ Matched sample } \\
\hline & (1) & (2) & (3) & (4) \\
\hline CAP $\times$ GALMA $\left(\right.$ DA $\left._{\text {Jones }}\right)$ & $\begin{array}{l}-0.0122 \\
(-0.99)\end{array}$ & $\begin{array}{l}-0.0137 \\
(-1.10)\end{array}$ & $\begin{array}{l}-0.0110 \\
(-0.80)\end{array}$ & $\begin{array}{l}-0.0112 \\
(-0.81)\end{array}$ \\
\hline CAP $\times$ GALMA $\left(\right.$ DA $\left._{\text {modJones }}\right)$ & $\begin{array}{l}-0.0107 \\
(-0.87)\end{array}$ & $\begin{array}{l}-0.0124 \\
(-1.00)\end{array}$ & $\begin{array}{l}-0.0141 \\
(-0.96)\end{array}$ & $\begin{array}{l}-0.0144 \\
(-0.98)\end{array}$ \\
\hline OCF $\times$ CAP $\times$ GALMA & $\begin{array}{l}-0.0308 \\
(-0.71)\end{array}$ & $\begin{array}{l}-0.0319 \\
(-0.73)\end{array}$ & $\begin{array}{l}0.0184 \\
(0.81)\end{array}$ & $\begin{array}{l}0.0176 \\
(0.77)\end{array}$ \\
\hline$E_{t-1} \times \mathrm{CAP}_{t} \times \mathrm{GALMA}_{t}$ & $\begin{array}{l}0.1653 \\
(1.03)\end{array}$ & $\begin{array}{l}0.1662 \\
(1.04)\end{array}$ & $\begin{array}{l}0.0366 \\
(0.21)\end{array}$ & $\begin{array}{l}0.0614 \\
(0.35)\end{array}$ \\
\hline Difference in mean $\left|v_{t} / E_{t}\right|$ for capitalizing companies & 0.4525 & 0.4363 & 0.7310 & 0.6439 \\
\hline$p$ value & 0.4027 & 0.4095 & 0.4015 & 0.4463 \\
\hline Industry fixed effects? & No & Yes & No & Yes \\
\hline$N$ & 646 & 646 & 461 & 461 \\
\hline
\end{tabular}

The results of the coefficients of interest for the subsample of companies with R\&D activities. There are 646 firm-year observations of companies with R\&D activities, of which 339 firm-year observations are from companies that are capitalizers. CAP is an indicator variable that equals one if the company is capitalizing R\&D costs. All variables are as previously defined. The significance of mean differences regarding the ability to predict earnings is assessed by $t$ test

$t$ statistics are in parentheses, and $* / * * / * * *$ marks significance at the $p<0.10 / p<0.05 / p<0.01$ levels, respectively

predictability of earnings lead to the same conclusion. The significance of the results does not differ for our full and our propensity score matched sample.

Overall, the results reveal no differences in financial reporting properties, even for those firms that should benefit from the new accounting rules. However, the financial reporting property measures evaluate only the difference in financial numbers and disregard possible improvements in disclosures. As previously mentioned in Sect. 2, firms that decide to capitalize their R\&D costs must provide mandatory disclosures related to their $R \& D$ activities in notes that outline the total amount of $R \& D$ costs and the related amount of capitalized $R \& D$ costs $(\S 285$, no. 22 German GAAP). Those firms are also required to present their R\&D assets separately on the balance sheet ( $\$ 266$ (2) German GAAP) and to explain the development of the asset over the fiscal year in notes ( $\$ 284$ (3), German GAAP). We analyze the annual reports of capitalizing firms in the adoption year and check whether they disclose the required information. In addition, we also search for additional voluntary disclosures. This additional information may include disclosures regarding the $\mathrm{R} \& \mathrm{D}$ project for which development costs are capitalized and/or disclosures related to the valuation of the $R \& D$ asset. The results are displayed in Table 13.

It is remarkable that only $80.65 \%$ of firms report information for total R\&D expenses, despite the fact that the regulator requires this disclosure. In addition, only $35.48 \%$ provide additional information voluntarily. This additional information is crucial for addressees of financial statements to understand whether the R\&D project is successful. 
Table 13 Subsample analysis on disclosure in firms capitalizing R\&D costs

\begin{tabular}{lc}
\hline & Percentage \\
\hline Amount of total R\&D costs & $80.65 \%$ \\
Amount of capitalized R\&D costs & $98.39 \%$ \\
Information on R\&D projects regarding capitalized R\&D costs & $35.48 \%$ \\
Development of R\&D assets & $93.55 \%$ \\
Information on valuation of R\&D assets & $35.48 \%$ \\
Separate presentation on the balance sheet & $90.32 \%$ \\
Disclosure of information required in German GAAP & $75.81 \%$ \\
Disclosure of mandatory and voluntary information & $16.13 \%$ \\
Total observations & 62 \\
\hline
\end{tabular}

The analysis on disclosure in the financial statements within a subsample of firms capitalizing R\&D costs. The analysis consists of financial statements for the year the German Accounting Law Modernization Act was adopted

Most companies describe all the R\&D projects; however, they do not mention to what $\mathrm{R} \& \mathrm{D}$ project the capitalized development costs are related. If firms disclose this information, they mostly mention capitalized development costs for software. Disclosure regarding the valuation of R\&D assets also can be improved. Only a few firms mention the components of the production costs and/or the useful life of the asset. Table 13 reveals that approximately $75.81 \%$ of firms offer all the required information, but only $16.13 \%$ provide all obligatory and voluntary information in addition. ${ }^{10}$

\subsection{Subsample of random firms with other provisions}

\subsubsection{Method for subsample of random firms with other provisions}

In addition, we further investigate the relationship between disclosure and the effects of the German Accounting Law Modernization Act on financial reporting properties by examining companies' disclosure behavior regarding other provisions. We choose this balance sheet item based on the previously described significant changes regarding measurement after the German Accounting Law Modernization Act, such as consideration of future wage and salary adjustments and the required discounting of other provisions with a maturity over 12 months. Other provisions offer an appropriate possibility to investigate companies' willingness to disclose information because $\S 285$ (12) German GAAP only provides the vague formulation that companies must disclose more information on specific other provisions when

\footnotetext{
${ }^{10}$ Based on this subsample analysis, we construct a disclosure score and investigate whether an effect of the German Accounting Law Modernization Act is only observable for those companies that disclose more information regarding their R\&D activities. Our results indicate that there are no differences in the effects of the German Accounting Law Modernization Act on financial reporting properties (not tabulated). Nevertheless, the directions of all interaction terms are consistent with our expectations that a decrease in discretionary accruals and income smoothing and an increase in earnings persistence and predictability could only be observable for those companies that benefit from the new accounting rules and disclose all relevant information. Our non-significant results might also be attributable to the small number of observations in our subsample.
} 
Table 14 Subsample analysis of disclosure of other provisions

\begin{tabular}{lc}
\hline & Percentage \\
\hline Value of other provisions & $100.00 \%$ \\
Settlement amount & $53.67 \%$ \\
Explicit rate for consideration of future wage and salary adjustments & $14.67 \%$ \\
Discounting other provisions & $51.67 \%$ \\
Explicit discount rate & $16.11 \%$ \\
Explanation of measurement changes & $16.33 \%$ \\
Total observations & 300
\end{tabular}

The analysis of the disclosure of other provisions in financial statements within a subsample of randomly chosen firms. The analysis consists of the financial statements of the adoption year of the German Accounting Law Modernization Act

there is no separate presentation in the balance sheet and recent other provisions are worth a substantial amount. The term "substantial" is open to interpretation.

Therefore, we randomly select 300 first-time adopting companies from a subsample of firm-year observations from 2009 and 2010 with other provisions reporting under German GAAP. Our random sample consists of 297 mandatory and 3 early adopters of GALMA. We hand-collected the disclosure information of interest and built a disclosure score following the approach for companies with $\mathrm{R} \& \mathrm{D}$ activities described in the previous section.

\subsubsection{Results for subsample of random firms with other provisions}

Table 14 reveals that only a small number of companies disclose information on other provisions. Approximately, 54\% of firms disclose the information that their other provisions are valued at their settlement amount under consideration of future events. Although there is no explicit prescription under German GAAP that companies must disclose information for all other provisions, § 285 (12) German GAAP clarifies that companies must disclose more information on specific other provisions when there is no separate presentation in the balance sheet and the recent other provisions are worth a substantial amount. Nevertheless, the German Accounting Law Modernization Act had a massive impact on the measurement of other provisions and the disclosure of measurement changes should be more fully explained. Nonetheless, only $15 \%$ report the explicit rate for consideration of future wage and salary adjustments.

Second, we investigate whether companies disclose information on discounting their other provisions. The results of the investigation regarding disclosure of the discounting effects are similar to those of disclosure in consideration of future wage and salary adjustments, as approximately $52 \%$ disclose this information voluntarily. However, it might be argued that the rest of the companies have only other provisions with maturities of less than 1 year. Nevertheless, even in this case, readers of financial statements would appreciate this information because, otherwise, they will not know anything about the maturity structure of other provisions. Our disclosure investigation reveals that all companies without 
discounting information did not publish any information regarding the maturity structure of their other provisions. Many companies indicate that they use the required 7-year averaged discount rate published by the German Central Bank. As those companies do not disclose any information regarding the maturity structure of their other provisions, the disclosed information is useless. Only $16 \%$ disclose their discount rate explicitly and only $16 \%$ explain measurement changes or differences resulting from the adoption of the German Accounting Law Modernization Act. In summary, our investigation of disclosure compliance for other provisions also reveals substantial variation.

Based on the previously described vague formulation that companies must disclose more information on other provisions when there is no separate presentation in the balance sheet and the corresponding other provisions are worth a substantial amount, we investigate whether we observe a relationship between the disclosure of other provisions and the ratio of other provisions and total assets. Surprisingly, we do not observe any relationship between those two variables.

\section{Conclusions and limitations}

The aim of the German Accounting Law Modernization Act was to align German GAAP with IFRS and therefore to improve the information provided in German financial statements. The new German GAAP should offer an alternative to IFRS that is more cost-effective and simpler to manage in practice (RegE BilMoG 2008). To fulfill the objective of increasing the information in German financial statements, the German regulator abolished numerous accounting options (see an overview in Table 1). However, the German Accounting Law Modernization Act also introduced several new accounting options (including capitalized R\&D costs) and modified the accounting rules to offer more flexibility (e.g., valuation of provisions). Thus, it is unclear whether and how the new accounting rules will affect accounting practice in Germany.

The first part of the study focuses on the research question about whether the German Accounting Law Modernization Act had an effect on financial reporting properties using four accounting-based financial reporting property measures: the magnitude of absolute discretionary accruals, the correlation between accruals and operating cash flow, the persistence of earnings, and the predictability of earnings. The results are mixed. The main analysis demonstrates a greater amount of absolute discretionary accruals but no change in income smoothing after adoption of the new rules. In addition, there is no change in either the persistence or the predictability of earnings. To control for differences in firm characteristics between companies reporting under German GAAP and those reporting under IFRS, we also employ propensity score matching for all our analyses and do not observe any significant changes in all financial reporting properties. Furthermore, we find no differences in all financial reporting property measures for the subsample of voluntary adopters and firms capitalizing R\&D costs.

The second part of the study focuses on disclosure after the adoption of the new accounting rules. For a subgroup of firms that voluntarily choose to capitalize R\&D 
costs and a randomly chosen subgroup of companies with other provisions, we investigate the amount of disclosure. The results for companies with capitalized R\&D costs reveal that approximately $25 \%$ of firms do not fulfill all of the disclosure requirements and that only a few firms provide additional information voluntarily. The same holds for our randomly selected subgroup of companies with other provisions, in which all disclosure information is implicitly discretionary, as $\S 285$ (12) of German GAAP clarifies only that disclosure of more information on specific other provisions is mandatory when there is no separate presentation in the balance sheet and when the recent other provisions have substantial value. Thus, we observe substantial variation for both investigations in disclosure compliance. Exploring the determinants of the cross-sectional variance in disclosure compliance appears to be an attractive avenue for future research.

In summary, this study shows no clear changes in financial reporting properties following the adoption of the new accounting rules. However, this investigation has some caveats. First, the prior literature shows no consensus view regarding the correct outcome measure for investigating the reporting and accounting practices of German private firms. Thus, our financial reporting properties might not be suitable measures for capturing a potential effect of the German Accounting Law Modernization Act, and future research could use alternative outcome measures. Second, our propensity score matching approaches rely on the assumption that the decision either to report under German GAAP or to voluntary adopt the German Accounting Law Modernization Act is solely determined by observables. Thus, we cannot exclude the possibility that these decisions might also depend on unobservable or omitted influential factors. Third, the number of observations after adoption of the new rules is limited because the new accounting standards affected the majority of financial statements for the first time in 2010. In addition, the first years of applying the new set of standards are subject to several transition options that might have influenced accounting numbers. Finally, it is possible that firm disclosures will improve over time as a result of a learning curve. Thus, future research might provide more insights on accounting and disclosure practice in German firms using a larger number of observation years.

Acknowledgments We acknowledge helpful comments from Joachim Gassen (the editor) and two anonymous reviewers. Furthermore we thank our supervisor Michael Hommel and Jannis Bischof for their constructive comments.

Open Access This article is distributed under the terms of the Creative Commons Attribution 4.0 International License (http://creativecommons.org/licenses/by/4.0/), which permits unrestricted use, distribution, and reproduction in any medium, provided you give appropriate credit to the original author(s) and the source, provide a link to the Creative Commons license, and indicate if changes were made.

\section{References}

BDI, Ernst \& Young, and DHBW Stuttgart. 2011. Das Bilanzrechtsmodernisierungsgesetz in der Praxis mittelständischer Unternehmen. Berlin: Industrie-Förderung $\mathrm{GmbH}$. 
Ball, Ray, Ashok Robin, and Joanna S. Wu. 2003. Incentives versus standards: properties of accounting income in four East Asian countries. Journal of Accounting and Economics 36 (1-3): 235-270.

Barth, Mary.E., Wayne R. Landsman, and Mark H. Lang. 2008. International accounting standards and accounting quality. Journal of Accounting Research 46 (3): 467-498.

Caliendo, Marco, and Sabine Kopeinig. 2008. Some practical guidance for the implementation of propensity score matching. Journal of Economic Surveys 22 (1): 31-72.

Christensen, Hans B., Edward Lee, Martin Walker, and Cheng Zeng. 2015. Incentives or standards: what determines accounting quality changes around IFRS adoption? European Accounting Review 24 (1): 31-61.

Daske, Holger, Luzi Hail, Christian Leuz, and Rodrigo Verdi. 2013. Adopting a label: heterogeneity in the economic consequences around IAS/IFRS adoptions. Journal of Accounting Research 51 (3): 495-547.

DeFond, Mark L., and James Jiambalvo. 1994. Debt covenant violation and manipulation of accruals. Journal of Accounting and Economics 17 (1-2): 145-176.

Dechow, Patricia M. 1994. Accounting earnings and cash flows as measures of firm performance: the role of accounting accruals. Journal of Accounting and Economics 18 (1): 3-42.

Dechow, Patricia M., Scott A. Richardson, and Irem Tuna. 2003. Why are earnings kinky?: an examination of the earnings management explanation. Review of Accounting Studies 8 (2-3): 355-384.

Dechow, Patricia M., Richard G. Sloan, and Amy P. Sweeney. 1995. Detecting earnings management. The Accounting Review 70 (2): 193-225.

Dehejia, Rajeev H., and Sadek Wahba. 2002. Propensity score-matching methods for nonexperimental causal studies. The Review of Economics and Statistics 84 (1): 151-161.

Dumontier, Pascal, and Bernard Raffournier. 1998. Why firms comply voluntarily with IAS. Journal of International Financial Management and Accounting 9 (3): 216-245.

Eierle, Brigitte, and Simone Wencki. 2014. Wird das Wahlrecht zur Aktivierung von Entwicklungskosten vom deutschen Mittelstand angenommen? Der Betrieb 67 (19): 1029-1036.

Francis, Jennifer, Ryan LaFond, Per M. Olsson, and Katherine Schipper. 2004. Costs of equity and earnings attributes. The Accounting Review 79 (4): 967-1010.

Froschhammer, Matthias, and Axel Haller. 2012. IFRS-Konvergenz im Rahmen der BilMoGErstanwendung-Eine empirische Analyse. Zeitschrift für internationale und kapitalmarktorientierte Rechnungslegung 12 (1): 17-25.

Gassen, Joachim, Jochen Pierk, and Matthias Weil. 2011. Pensionsrückstellungen nach dem BilMoGErste empirische Evidenz. Der Betrieb 64 (19): 1061-1067.

Gassen, Joachim, and Thorsten Sellhorn. 2006. Applying IFRS in Germany-determinants and consequences. Betriebswirtschaftliche Forschung und Praxis 58 (4): 365-386.

Gross, Christian. 2016. The Effect of the German Accounting Law Modernization Act on the Comparability of Private Local GAAP and IFRS Firms. Schmalenbach Business Review 17 (3): 423-460.

Heckman, James J., Hidehiko Ichimura, and Petra Todd. 1998. Matching as an econometric evaluation estimator. Review of Economic Studies 65 (2): 261-294.

Heckman, James, and Salvador Navarro-Lozano. 2004. Using matching, instrumental variables and control functions to estimate economic choice models. The Review of Economics and Statistics 86 (1): 30-57.

Jones, Jennifer J. 1991. Earnings management during import relief investigations. Journal of Accounting Research 29 (2): 193-228.

Keitz, Isabel von, and Thomas Gloth. 2013. Praxis ausgewählter HGB-Anhangangaben-Eine empirische Analyse von 54 Jahresabschlüssen. Der Betrieb 66 (4): 129-138, 185-194.

Keitz, Isabel von, Marc Oliver Wenk, and Christian Jagosch. 2011. HGB-Bilanzierungspraxis nach BilMoG-Eine empirische Analyse von ausgewählten Familienunternehmen. Der Betrieb 64 (44): 2445-2450, 2503-2508.

Kothari, S.P., Andrew J. Leone, and Charles E. Wasley. 2005. Performance matched discretionary accrual measures. Journal of Accounting and Economics 39 (1): 163-197.

Lawrence, Alastair, Miguel Minutti-Meza, and Ping Zhang. 2011. Can Big 4 versus non-Big 4 differences in audit-quality proxies be attributed to client characteristics? The Accounting Review 86 (1): 259-286. 
Leuz, Christian, and Jens Wüstemann. 2004. The role of accounting in the German financial system. In: The German Financial System, ed. Jan Pieter Krahnen and Reinhard H. Schmidt, 450-485. Oxford: Oxford University Press.

Leuz, Christian, Dhananjay Nanda, and Peter D. Wysocki. 2003. Earnings management and investor protection: an international comparison. Journal of Financial Economics 69 (3): 505-527.

Lev, Baruch. 1983. Some economic determinants of time-series properties of earnings. Journal of Accounting and Economics 5 (1): 31-38.

Lipe, Robert. 1990. The relation between stock returns and accounting earnings given alternative information. The Accounting Review 65 (1): 49-71.

Lopatta, Kerstin, Thomas Kaspereit, Reemda Jaeschke, and Gesa Stockem. 2013. The effects of the German Accounting Law Modernization Act (BilMoG) on the earnings quality of private firms. Corporate Finance Law 4 (5): 234-242.

Petersen, Mitchell A. 2009. Estimating standard errors in finance panel data sets: comparing approaches. Review of Financial Studies 22 (1): 435-480.

Pierk, Jochen, and Matthias Weil. 2012. Konvergenz von IFRS und HGB am Beispiel der Pensionsrückstellungen kapitalmarktorientierter Unternehmen. Zeitschrift für internationale und kapitalmarktorientierte Rechnungslegung 12 (11): 516-521.

Pierk, Jochen, and Matthias Weil. 2016. Price regulation and accounting choice. Journal of Accounting and Public Policy 35 (1): 256-275.

RegE BilMoG. 2008. Gesetzentwurf der Bundesregierung-Entwurf eines Gesetzes zur Modernisierung des Bilanzrechts, BT-Drucksache 16/10067.

Regulation (EC) No. 1606/2002 of the European Parliament and of the Council of July 19, 2002 on the application of international accounting standards, No. L 243.

Rosenbaum, Paul R., and Donald B. Rubin. 1985. Constructing a control group using multivariate matched sampling methods that incorporate the propensity score. The American Statistician 39 (1): 33-38.

Rubin, Donald B. 1979. Using Multivariate Matched Sampling and Regression Adjustment to Control Bias in Observational Studies. Journal of the American Statistical Association 74 (366): 318-328.

Schipper, Katherine, and Linda Vincent. 2003. Earnings quality. Accounting Horizons 17 (Supplement): 97-110.

Watts, Ross L., and Jerold L. Zimmerman. 1986. Positive Accounting Theory. Englewood Cliffs: Prentice Hall. 